\title{
The swing of the pendulum: reputation, expression and the re-centring of English libel law
}

\author{
Alastair Muluis \\ University of East Anglia \\ ANDREW SCOTT ${ }^{*}$ \\ London School of Economics and Political Science
}

\section{Introduction}

$\mathrm{T}$ The task of designing any libel regime must involve reaching an appropriate accommodation between individual rights and social interests in both freedom of expression and reputation. ${ }^{1}$ English libel law has long been criticised for its failure properly to reflect the importance of freedom of expression. Significant revisions have been made to law and practice in the area over the past two decades in the hope of addressing this concern. Much scholarship has reported on the shortcoming over time, and offered varied proposals for further reform. ${ }^{2}$ In recent times, vociferous political campaigning has been dedicated towards asserting that problems persist still. ${ }^{3}$ Given the egregious restriction that it once imposed on freedom of speech, it is perhaps unsurprising that so much modern thinking and action regarding libel law has emphasised the need better to valorise expression interests. The "constitutionalisation" of libel law has been viewed largely through the prism of Article 10 of the European Convention on Human Rights (ECHR) alone.

One consequence of this orientation has been that the need to defend reputation has been subordinated. As we explain in the first part of this paper, in the period before and for some years after the passing of the Human Rights Act 1998, the approach of courts to the need to balance expression and reputation interests focused almost exclusively on the question of whether existing rules of law were compliant with Article 10. The importance of reputation was not ignored, but freedom of expression was regarded as the "trump card". Reputation interests were considered only as a possible limitation on the

* We owe an especial debt of thanks to Cameron Doley, Eric Barendt and Benjamin Pell for developed feedback on this paper. All errors and omissions remain our own.

1 Access to justice is also key, both for defendants and claimants. Indeed, it may be in this respect that the English libel regime can be considered to have been - and to remain - most inadequate.

2 Notable in this regard have been E Barendt, L Lustgarten, K Norrie, H Stephenson, Libel and the Media: The chilling effect (Oxford: OUP 1997); I Loveland, Political Libels: A comparative study (Oxford: Hart 2000), and D Milo, Defamation and Freedom of Speech (Oxford: OUP 2008).

3 Index on Censorship/English PEN, Free Speech is not for Sale (2009); Reforming Libel: What should a defamation bill contain? (2011), both available at www.libelreform.org (accessed April 2011). 
right to freedom of expression where this could be demonstrated to be necessary in a democratic society. ${ }^{4}$

In the light of developments in European and English jurisprudence, this approach is no longer tenable. The Strasbourg and domestic courts have, since 2004, become progressively more pronounced in recognising that reputation falls to be protected under the Article 8 right to respect for private life. They have recognised a Convention right to the protection of reputation. ${ }^{5}$ Hence, to the extent that it was thought that freedom of expression would always be the more important right, this is no longer the case. Today, at least in respect of most defamation claims, the court is required instead to weigh the competing interests of the claimants under Article 8 and the defendants under Article 10. In all cases, societal interests in the protection of individuals' reputations will also be in play. The second part of this paper charts the early development and deployment of the Article 8 right to reputation in European and domestic jurisprudence.

Yet, while this jurisprudential innovation is now embedded at both the European and domestic levels, it is not clear that a coherent intellectual underpinning has been articulated by the courts. The third part of this paper reviews four main justifications offered by judges and others to explain the articulation between reputation and privacy. Relying on the social psychology literature on reputation, the paper presents the expansion of Article 8 to cover reputation as an appropriate - indeed, as a necessary - development. It reprises and develops a dualistic understanding of reputation and explanation for its legal protection as proffered by the Strasbourg Court in Karako v Hungary, ${ }^{6}$ centred on potential harms wrought on one hand to public perceptions of the character of an individual, and on the other hand that individual's sense of self-esteem engendered by the quality of this public regard. It suggests that only in the latter respect should reputation fall within the ambit of Article 8 . The fourth part of the paper draws out a number of general repercussions of this understanding of Article 8 protection for reputation.

While the theoretic underpinning of the domestic courts' jurisprudence is as yet underdeveloped, there is a real likelihood that - whatever the outcomes of current parliamentary considerations - the coming years will see significant changes in the law of defamation as the implications of the new approach are worked through. We consider a number of the possible ramifications of the rights-based resurgence of reputation in the final part of the paper. Properly applied and understood, this approach does have the capacity to lead to a re-centring of the law that would validate the rights of claimants, defendants and the wider public, at least insofar as the substantive law of defamation is concerned.

\section{Reaching the zenith: the rise and rise of freedom of expression}

Any law of libel devised so as to defend reputations against the fall-out from unjustified criticism will necessarily constrain freedom of speech. A balance must be struck between the underpinning values served by the law and the individual and social benefits of free and open discussion. Historically, English libel law was much-criticised for striking this balance

4 Article 10(2) ECHR provides for the subjection of the Article 10(1) right to such formalities, conditions, restrictions or penalties as are prescribed by law and are necessary in a democratic society, inter alia, for the protection of the reputation or the rights of others.

5 See, for example, the following Strasbourg decisions: Chauvy v France (2005) 40 EHRR 610, at [70]; Radio France v France (2005) 40 EHRR 29, at [31]; Cumpănă and Mąăre v Romania (2005) 41 EHRR 200, at [91]; White v Sweden (2008) 46 EHRR 3; Lindon, Otchakovsky-Laurens and July v France (2008) EHRR 35. For English cases, see: Re Guardian News and Media Ltd [2010] UKSC 1; Re Attorney-General's Reference No 3 of 1999 [2009] UKHL 34; Clift v Slough Borough Council [2009] EWHC 2375; Flood v Times Newspapers [2009] EWHC 2375; Brady v Norman [2010] EWHC 1215; Ronaldo v Telegraph Media Group Ltd [2010] EWHC 2710.

6 (2011) 52 EHRR 36. 
in an overly restrictive manner. Damages awards had become exorbitant, ${ }^{7}$ no public interest defence existed (aside from those implied in traditional qualified privilege), and strict liability was the invariable rule. That some adjustment to the law was necessary could not be sensibly contested. The years immediately before and after the passing of the Human Rights Act 1998, however, were in fact characterised by just such a significant rebalancing in the law of defamation in favour of freedom of expression. The extent of the reshaping that occurred should not be underestimated. ${ }^{8}$

The rebalancing of the law began well before the passage of the 1998 Act. In several cases Article 10 ECHR was identified expressly as a factor influencing determinations of the courts. A significant decision concerning standing to sue was that of the House of Lords in Derbyshire CC v Times Newspapers. ${ }^{9}$ In concluding that a local authority did not have the right to maintain an action for damages in defamation, the Court of Appeal had relied directly on the Convention. ${ }^{10}$ On appeal, the House of Lords decided the case on the basis of domestic law, but nevertheless expressed the view that English law was Convention compliant. ${ }^{11}$ Subsequently, Buckley J determined that a political party also cannot sue in defamation. ${ }^{12}$ Again the importance of freedom of expression was emphasised. ${ }^{13}$

A second significant change occurred in relation to the assessment of damages. In a series of cases the most significant of which were Rantzen v Mirror Group Newspapers ${ }^{14}$ and $J o h n \mathrm{v} M G N,{ }^{15}$ the courts made clear that the days when libel awards could be regarded as "a road to untaxed riches" were over. The immediate catalyst for this change was the passing of s. 8 of the Courts and Legal Services Act 1990. This gave the Court of Appeal a discretion to intercede where damages awarded were excessive (or inadequate) and to substitute its own award for that of the jury. The Court of Appeal in Rantzen required that the exercise of this discretion should take Article 10 and related Strasbourg jurisprudence into account. ${ }^{16}$ It also highlighted the requirements articulated by Lord Goff in $A-G \mathrm{v}$ Guardian Newspapers Ltd (No 2): that any interference with the right to freedom of expression had to be justified by the existence of a pressing social need, and that where interference was justified it should be no more than is proportionate to the legitimate aim

7 See e.g. Lord Aldington v Count Tolstoy, The Guardian, 1 December $1989(£ 1.5 \mathrm{~m}$ awarded in respect of an allegation that the claimant was a war criminal); Stark v Mirror Group Newspapers, The Times, 4 November 1988 ( $f 300,000$ awarded to an actress for an imputation that she retained a "lingering love" for her former boyfriend and had secret meetings with him after marrying someone else); Archer v Express Newspapers, The Times, 25 July 1987 ( $£, 500,000$ for an allegation that the claimant had paid a prostitute for sex and subsequently lied about it).

8 This primacy afforded to freedom of expression was also reflected in the jurisprudence of the European Court of Human Rights during this period - see generally G Millar, "Whither the spirit of Lingens?" (2009) European Human Rights Law Review 277-88.

$9 \quad$ [1993] AC 534.

10 [1992] QB 770. Balcombe LJ noted that the common law and the Convention were entirely consonant and hence analysed the case using the framework provided by the Convention (at $811 \mathrm{ff}$.). Ralph Gibson LJ and Butler-Sloss LJ were somewhat more circumspect on the relevance of the Convention, but given what they perceived as an ambiguity and lack of clarity on point they each ultimately adopted the same analysis. In the Divisional Court, Morland J had decided the case in favour of the local authority, indicating that no explicit regard should be given to the Convention (at 787).

11 [1993] AC 534, at 551 (per Lord Keith).

12 Goldsmith v Bhoyrul [1998] QB 459.

13 Ibid. at 462.

14 [1994] QB 670.

15 [1996] 2 All ER 35.

16 [1994] QB 670, at 691. 
pursued. ${ }^{17}$ In John v MGN, the Court of Appeal returned to the issue of excessive damages and - although stating that the conclusion was reached independently of the Convention effected additional change to the law to avoid the possibility of excessive awards. This took the form of requiring extensive guidance to be given by the judge to the jury. The practical result of these decisions has been a substantial decrease in the average award of damages over the last two decades. ${ }^{18}$ An effective damages cap has been fixed in line with awards for non-pecuniary loss in personal injury cases.

The judgment most closely associated with the "constitutionalisation" of libel law is that of the House of Lords in Reynolds $\mathrm{v}$ Times Newspapers. ${ }^{19}$ In that case, and the later decision in Jameel $\mathrm{v}$ Wall Street Journal, ${ }^{20}$ their Lordships held that where a publication is on a matter of public interest, a defendant who cannot prove the truth of statements made is protected by privilege where it can be shown that the defendant's conduct was nevertheless responsible. As with the Derbyshire decision, ${ }^{21}$ the Human Rights Act 1998 was not in force at the time Reynolds was decided. Rather, it was common ground that the case should be determined on the basis that the Act would soon be in force. ${ }^{22}$ Though it is true to say that the importance of reputation was not wholly overlooked, Lord Nicholls' leading speech placed freedom of expression to the fore: "my starting point is freedom of expression ... the crux of this appeal, therefore, lies in identifying the restrictions [on freedom of expression] which are fairly and reasonably necessary for the protection of reputation". ${ }^{23}$ In similar vein, Lord Steyn stated:

the starting point is now the right of freedom of expression, a right based on a constitutional or higher legal order foundation. Exceptions to freedom of expression must be justified as being necessary in a democracy. In other words, freedom of expression is the rule and regulation of speech is the exception requiring justification. The existence and width of any exception can only be justified if it is underpinned by a pressing social need. These are fundamental principles governing the balance to be struck between freedom of expression and defamation. ${ }^{24}$

For their Lordships, therefore, while reputation was an important value expressly identified in Article 10(2) of the Convention that deserved protection, ${ }^{25}$ freedom of speech had a higher normative force. Restrictions or exceptions designed to protect reputation might be justified, but only if the restriction they entailed was necessary and proportionate in light of that pressing social need.

In light of concerns that Reynolds privilege was not having the liberating effect on freedom of expression that had been anticipated, the House of Lords took the opportunity in Jameel $\mathrm{v}$ Wall Street Journal Europe to restate its underpinning principles. ${ }^{26}$ The unmistakable message infusing the speeches is that prior to the Human Rights Act 1998 the

17 [1990] 1 AC 109.

18 For the raw data, see C Doley and A Mullis (eds), Carter-Ruck on Libel and Privacy 6th edn (London: Butterworths 2010), appendix on damages in defamation claims.

19 Reynolds $\mathrm{v}$ Times Newspapers [2001] 2 AC 127.

20 [2006] UKHL 44, [2007] 1 AC 359.

21 [1993] AC 534.

22 See, for example, [2001] 2 AC 127, at 200 (per Lord Nicholls), at 207-8 (per Lord Steyn), and at 223 (per Lord Cooke).

23 Ibid. at 200-1.

24 Ibid. at 208.

25 Ibid. at 201 (per Lord Nicholls).

26 [2006] UKHL 44, [2007] 1 AC 359. 
law of defamation was too heavily weighted against freedom of expression and that this position was no longer tenable. As Lord Hoffmann explained:

until very recently, the law of defamation was weighted in favour of claimants and the law of privacy weighted against them. True but trivial intrusions into private life were safe. Reports of investigations by the newspaper into matters of public concern which could be construed as reflecting badly on public figures domestic or foreign were risky. The House attempted to redress the balance in favour of privacy in Campbell v MGN Ltd and in favour of greater freedom for the press to publish stories of genuine public interest in Reynolds $\mathrm{v}$ Times Newspapers. But this case suggests that Reynolds has had little impact upon the way the law is applied at first instance. It is therefore necessary to restate the principles. ${ }^{27}$

As was the case in Reynolds, their Lordships proceeded on the basis that, while restrictions on the right to freedom of expression could be justified by the need to protect reputation, any such restriction must be "necessary in a democratic society". The value of reputation was recognised, but the primacy of freedom of expression was to be treated as the starting point.

Further important shifts in the law reflecting the dominant influence of Article 10 and freedom of expression followed the advent of the Human Rights Act 1998. These include the development of the abuse of process jurisdiction, the emergence of the defence of reportage, the abandonment of the strict liability principle in so-called "look-alike" cases, and the broadening of the fair comment defence. The abuse of process jurisdiction derives from the decision of the Court of Appeal in Jameel $v$ Dow Jones \& Co Ltd and provides for the court to strike out claims where no "real and substantial tort" is at issue. ${ }^{28}$ It is intended to ensure that the proceedings will be halted if there is no realistic prospect of a trial yielding any tangible or legitimate advantage that would justify either the expense to which the parties will be put and/or the dedication of court resources. In reaching its conclusion, the Court of Appeal recognised that it was appropriate to have regard to Article $10 \mathrm{ECHR}$ in deciding whether a claim should be allowed to proceed at all, and that consideration of freedom of expression could not be left to be addressed only at the stage when a defendant was serving a defence. While a number of applications to strike out for abuse of process have been unsuccessful, 29 a good number of defendants have persuaded the court to strike claims out. ${ }^{30}$

27 [2006] UKHL 44, [2007] 1 AC 359, at 378 (Lord Hoffmann dissented on the question whether a company, with a trading reputation in the UK but not otherwise resident in England or Wales, could bring a claim in defamation without proving damage but not on the Reynolds privilege issue).

28 [2005] QB 946; [2005] 2 WLR 1614; [2005] EWCA Civ 75.

29 These have included Lewis $\mathrm{v}$ Commissioner of Police of the Metropolis [2011] EWHC 781 (QB); McKeown v Attheraces Ltd [2011] EWHC 179 (QB); France v Freemans Solicitors [2010] EWHC 3291 (QB); Cairns v Modi [2010] EWHC 2859 (QB); Taylor v Associated Newspapers Ltd [2010] EWHC 2494 (QB); McLaughlin $\mathrm{v}$ London Borough of Lambeth [2010] EWHC 2726 (QB); Ronaldo v Telegraph Media Group Ltd [2010] EWHC 2710 (QB); Underbill v Corser [2010] EWHC 1195 (QB); Baturina v Times Newspapers Ltd [2010] EWHC 696 (QB); [2010] EMLR 18.

30 In the last three years, these cases have included Wallis v Meredith [2011] EWHC 75 (QB); Smith v ADV FN plc [2010] EWHC 3255 (QB); Kaschke v Gray [2010] EWHC 1907 (QB); Khader v Aziz [2010] EWCA Civ 716; [2010] 1 WLR 2673; [2011] EMLR 2 (confirming Khader v Aziz. [2009] EWHC 2027 (QB)); Brady v Norman [2010] EWHC 1215 (QB); Hays plc v Hartley [2010] EWHC 1068; Kaschke v Osler [2010] EWHC 1075 (QB); Budu v British Broadcasting Corporation [2010] EWHC 616 (QB); Williams v MGN Ltd [2009] EWHC 3150 (QB); Lonzim plc v Sprague [2009] EWHC 2838 (QB); Elton John v Guardian News \& Media Ltd [2008] EWHC 3066. On at least one occasion, the court has suggested that a Jameel application really should have been brought see Henderson v Hackney LBC [2010] EWHC 1651 (QB) at [42] - while on others it has been held that Jameel arguments added nothing to other grounds for striking out an action - see e.g. Bowker v Royal Society for the Protection of Birds [2011] EWHC 737 (QB). 
The reportage defence emerged fully formed in Al Fagih v HH Saudi Research and Marketing (UK) $L t d .^{31}$ While some debate exists as to its scope, ${ }^{32}$ in essence this development affords a defence to a defendant who provides a neutral and balanced report of attributed allegations without taking sides or embellishing the report. No authority was cited in support of the existence of such a defence, but it is not unreasonable to infer that the decision reflected the court's understanding of the particular importance of Article 10. For instance, Simon Brown LJ explained:

neither [freedom of expression nor the right of an individual to his good reputation] is absolute but the former, particularly in the field of political discussion, is of a higher order, a constitutional right of vital importance to the proper functioning of a democratic society. That is why "any curtailment of freedom of expression must be convincingly established by a compelling countervailing consideration, and the means employed must be proportionate to the end sought to be achieved" (per Lord Nicholls in Reynolds v Times Newspapers), and why "any lingering doubts (as to how the balance should be struck) should be resolved in favour of publication" (per Lord Nicholls in Reynolds $\mathrm{v}$ Times Newspapers). ${ }^{33}$

The position on strict liability in respect of look-alike cases was addressed in O'Shea v MGN Ltd. ${ }^{34}$ In that case, the defendants published an advertisement for an adult internet site. The advertisement included a photograph of a "glamour model". The claimant, a young woman who strongly resembled the model, brought a claim in libel, pleading that a number of persons had identified her with the photograph. After a careful review of prior jurisprudence, Morland J concluded that at common law the strict liability principle applied. He then proceeded, however, to consider the application of the Human Rights Act 1998 and whether application of the strict liability principle to look-alike cases was compatible with Article 10. In the judge's view, it was not: "to allow [the strict liability principle to apply to look-alike cases] ... would be an unjustifiable interference with the vital right of freedom of expression disproportionate to the legitimate aim of protecting the reputations of 'lookalikes' and contrary to Article 10". 35

As regards the development of the defence of fair comment, there have been a number of decisions in which Article 10, without being specifically relied upon as the basis for widening the ambit of the defence, was nevertheless clearly deemed a relevant consideration. Thus, in Hamilton $\mathrm{v}$ Clifford, Eady J commented that the greater readiness to treat inferences of fact as comment - reflected in cases such as Branson v Bower 36 - "was intended to clarify the law of fair comment and to ensure that English law was marching in step with the jurisprudence of the European Court of Human Rights". 37 So too in Lowe v Associated Newspapers, Eady J held that there was no need fully to set out the facts on which the comment was based to rely on the defence. ${ }^{38}$ In so holding, the learned judge stated:

31 [2001] EWCA Civ 1634. For critique, see G Busittil, "Reportage: a not entirely neutral report” [2009] Entertainment Law Review 44, and J Bosland, "Republication of defamation under the doctrine of reportage: the evolution of common law qualified privilege in England and Wales" (2011) 31 Oxford Journal of Legal Studies 89.

32 See Doley and Mullis, Carter-Ruck, n. 18 above, paras 12.131-41.

33 [2001] EWCA Civ 1634, at [26].

34 [2000] EMLR 40.

35 [2000] EMLR 40, at [47].

36 [2001] EWCA Civ 791. It should be said that the Court of Appeal in Branson stated that they decided the case by applying the traditional common law rule without the need to consider the extent to which it has been in anyway affected by the passing of the Human Rights Act 1998 (at [11]).

37 [2004] EWHC 1542, at [55].

38 [2006] EWHC 320. 
I am also required by the Human Rights Act to take into account Article 10 and the jurisprudence associated with it. Having regard to those considerations, I am left in no doubt that the right to comment freely on matters of public interest would be far too circumscribed if it were a necessary ingredient of the English common law's defence of fair comment that the commentator should be confined to pleading facts stated in the words complained of. It would be more consonant with Article 10, and the rights of a free press in a democratic society, if the restriction were expressed in terms of the "subject-matter". 39

Even in circumstances where the courts have held that the existing law was Convention compliant, the special importance of freedom of expression has been specifically recognised. In Jameel v Wall Street Journal Europe SPRL, for example, the House of Lords held that the rule that a trading company with a trading reputation in the jurisdiction was entitled to sue in libel without pleading or proving special damages is Convention compliant. ${ }^{40}$ While this was a majority decision, there was no disagreement between their Lordships on the importance of freedom of expression and the requirement that any restriction be both justified by a pressing social need and proportionate to the legitimate aim pursued. Rather, the difference of opinion lay instead in the appropriate weight to be given to the two interests. In Berezovsky v Forbes (No 2), the Court of Appeal confirmed that the English law rule requiring the defendant to prove the truth of the essence, substance or sting of a defamatory imputation was not a disproportionate invasion of the right to freedom of expression. ${ }^{41}$ So too, in Loutchansky v Times Newspapers Ltd and Others (Nos 2-5), the Court of Appeal concluded that the multiple publication rule did not constitute an unjustifiable restriction on the defendant's Article 10 rights. ${ }^{42}$

It is clear that the right to freedom of expression contained in Article 10 played a very significant role in the development of the law of defamation from the 1990s into the 2000s. While domestic courts did not overlook the importance of reputation, the clear direction of development of the law was such as to privilege freedom of expression. While there was one decision prior to 2005 in which an English court indicated that reputation may be among the rights protected by Article $8,{ }^{43}$ the prevailing view expressed in the caselaw was that freedom of expression was the higher right and that any restriction or exception to it had to be justified. The consequence of this was that the contours of the law had been significantly re-sculpted since the end of the 1980s. Damages were curtailed, a new public interest privilege was recognised, an abuse of process strike-out jurisdiction was acknowledged, the defence of fair comment was revitalised, and certain legal entities had been held to lack the capacity to bring a claim. Even in those cases where no change in the previous law was found necessary - as, for example, in relation to the multiple publication rule and the right of a trading corporation to sue in the absence of proof of damage - the

39 [2006] EWHC 320, at [42].

40 [2006] UKHL 44, [2007] 1 AC 359. Lord Hoffmann and Baroness Hale dissented.

41 [2001] EWCA Civ 1251, at [12].

42 [2001] EWCA Civ 1805 [2002] QB 783. The European Court of Human Rights has held that in this respect English law is Convention compliant although it suggested that should the law permit an action to be brought a very long period after the first publication this might prove to be too great a restriction of free expression - see, Times Newspapers (Nos 1 and 2) v United Kingdom Application [2009] EMLR 14.

43 Greene v Associated Newspapers [2004] EWCA Civ 1462, at [68] (per Brooke LJ): "for the purposes of this judgment we are content to assume that a person's right to protect his/her reputation is among the rights guaranteed by ECHR Article 8 (see Affaire Radio France et autres v France (No 53984/00) at para. 31)". Previously, in Grobbelaar v News Group Newspapers Ltd [2002] UKHL 40, Lord Hobhouse had mused: "Article 10 of the Convention for the Protection of Human Rights and Fundamental Freedoms is always important. But article 10(1) is subject to 10(2) and the English law of defamation gives effect to this and recognises that other human rights may be engaged as well, as for example under article 8(1)" (at [63] - emphasis added). 
law was carefully assessed for compliance with Article 10. While the English courts had not gone as far as their US counterparts in "constitutionalising" the law, the pendulum had swung significantly in favour of freedom of speech and the extent to which the law valorised reputation was much reduced.

\section{Castles on the sand? The early jurisprudence on reputation and Article 8}

If the period from the 1990s until 2005 was characterised by a special sensitivity for freedom of expression, by the end of that time the seeds of change were being sown by the European Court of Human Rights. While reputation is not expressly identified as a protected right under the Convention, in a series of cases beginning in 2004 the court recognised that it does fall within the right to respect for private life in Article 8. ${ }^{44}$ This idea is potentially of real significance. Once Article 8 protection for reputation is allowed, the traditional approach to the assessment of an alleged breach of Article 10 - the presumed priority of freedom of expression over the enunciated social interests, intervention in the pursuit of which must be clearly demonstrated to be necessary by the state authorities must transmute into a balancing exercise between competing Convention rights. On one hand, state parties would henceforth be able to offer a rights-based counterpoint where applicants challenged restrictions imposed by libel law on freedom of speech. On the other hand, because Article 8 imposes positive obligations on state parties to secure the substance of the right to their citizens, ${ }^{45}$ it would permit disgruntled libel claimants to apply to the Strasbourg court to contest the perceived failure of domestic laws to ensure respect for the right to reputation.

The first jurisprudential associations between the protection of reputation and the right to private life were made only in early-mid 2004. In Radio France v France, the court observed - in a passing reference only - that "the right to protection of one's reputation is of course one of the rights guaranteed by Article 8 of the Convention, as one element of the right to respect for private life". 46 This assertion has been described by one leading commentator as a "bombshell".47 Shortly afterwards, in Chamy v France, the court proceeded on the basis that the inclusion of an individual's reputation as a value actively protected under Article 8 was routine. ${ }^{48}$ The importance of this understanding was neither openly discussed nor readily apparent in the judgment. This shift was subsequently alluded to in similarly bare terms in a number of further cases in the following 18 months. ${ }^{49}$ It also

44 Arguments to this effect had previously been presented to the court without their validity being unequivocally confirmed - see Fayed v United Kingdom (1994) 18 EHRR 393 at [46] and [7] in the concurring opinion of Judge Martens; Niemietz v Germany (1993) 16 EHRR 97 at [37]; Rotaru v Romania Application No 28341/95, unreported 4 May 2000, at [13] in the partly dissenting opinion of Judge Bonello.

45 In Von Hannover v Germany (2005) 40 EHRR 1, for example, the European Court stated that "although the object of Article 8 is essentially that of protecting the individual against arbitrary interference by the public authorities, it does not merely compel the State to abstain from such interference: in addition to this primarily negative undertaking, there may be positive obligations inherent in an effective respect for private or family life. These obligations may involve the adoption of measures designed to secure respect for private life even in the sphere of the relations of individuals between themselves" (at [57]).

46 (2005) 40 EHRR 706, at [31]. The focus of the consideration had been on whether interference with applicants' right to freedom of expression, which had been based on the Article 10(2) ECHR purpose of protecting reputation, had been necessary in the circumstances of the instant case. The case concerned civil and criminal sanctions imposed upon a media company, its publishing director and a journalist on account of defamatory allegations made in a magazine article and interview and radio broadcasts.

47 Millar, "Whither the spirit", n 8 above, p. 281.

48 (2005) 41 EHRR 29, at [70].

49 See, for example, Cumpănă and Mazăre v Romania (2005) 41 EHRR 41, at [91]; White v Sweden (2008) 46 EHRR 3, at [26]; Leempoel v Belgium, Application No 64772/01, unreported, 9 November 2006, at [67]. 
found expression for the first time in the English Court of Appeal: in Greene v Associated Newspapers, the court was content to assume, relying on Chauvy v France, that a right to reputation was among the rights guaranteed by Article 8.50 None of the judgments included any developed analysis of the point.

The inclusion of reputation within the ambit of Article 8 was a surprising innovation as there had been a conscious decision to omit the reference to "honour and reputation" - that was present in Article 12 of the pre-existing Universal Declaration on Human Rights during the drafting of the provision. ${ }^{51}$ The obligation to protect reputation is mentioned explicitly only in the series of grounds in pursuit of which limitations may legitimately be placed upon the right to freedom of expression guaranteed under Article 10 ECHR. The Convention is generally regarded, however, as "a living reality capable of unlimited development". 52 The European Court is not bound by an obligation of dogmatic obedience to the progenitors of the document. Hence, reliance on the documented intent of the drafters cannot obviate in principle any interpretation of a provision that may be deemed appropriate in light of the exigencies of a given case. Moreover, it has long been accepted that the "right to privacy" "comprises other rights than those expressly mentioned in Article 8",53 and both the Consultative Assembly and the European Commission of Human Rights had formulated conceptions of the right that were broad enough to encompass reputation. ${ }^{54}$ Nevertheless, the new jurisprudence was clearly a significant departure from the original intent of the "framers" of the Convention.

The first strands of the developing jurisprudence were either recounted without comment or roundly rejected as unfounded and ahistorical in the periodic and scholarly literature. Fenwick and Phillipson considered the development to be "potentially of great significance", 55 but "somewhat counter-intuitive" and in some circumstances even "perverse". 56 Robertson and Nicol were more categoric in deriding what they considered

50 [2004] EWCA Civ 1462, at [68].

$51 \mathrm{~J}$ Velu, "The European Convention on Human Rights and the right to respect for private life, the home and communications", in A H Robertson (ed.), Privacy and Human Rights (Manchester: Manchester UP 1973), p. 16. In this respect at least, Judge Loucaides' argument in Lindon is untenable. He pronounced that following the experiences of the Second World War "it would have been inexplicable [for the authors of the Convention] not to provide direct protection of the reputation and dignity of the individual as a person" ((2008) 46 EHRR 35 , at [O-I6]). He asserted that, consequently, a "correct" interpretation of the Convention would always have seen the right to reputation safeguarded by Article 8 as "part and parcel of the right to respect for one's private life" (at [O-I5]). This view does not accord with the historic record which demonstrates that the omission of the protection of honour and reputation from the ambit of Article 8 was consciously intended.

52 Ibid. at p. 25 (quoting Eissen: "si l'on voit dans la Convention une réalité vivante appelée à se développer sans cesse, si l'on préfère aux délices stériles de l'exégèse la recherche de solutions à la fois respectueuses du droits et conformes au bien commun, pour écarter une possibilité de progrès, pourquoi repousser une idée féconde et généreuse?"). See, further, H Tomlinson, "Strasbourg on privacy and reputation: Pt 2 - a right to reputation?", Inforrm, 9 March 2010 .

53 P van Dijk and G J H van Hoof (1990) Theory and Practice of the European Convention on Human Rights (Deventer: Kluwer Law and Taxation Publishers), p. 368.

54 For instance, in Resolution 428 (1970) of the Consultative Assembly of the Council of Europe which contains the Declaration concerning the Mass Media and Human Rights it was stated that "the right to privacy consists essentially in the right to live one's own life with a minimum of interference. It concerns private, family and home life, physical and moral integrity, honour and reputation, avoidance of being placed in a false light, nonrevelation of irrelevant and embarrassing facts, unauthorised publication of private photographs, protection from disclosure of information given or received by the individual confidentially." In $X$ and $Y$ v Belgium, D \& R 28 (1982) 112 (124), the Commission also found that "the concept of privacy in Article 8 also includes, to a certain extent, the right to establish and maintain relations with other human beings for the fulfilment of one's personality".

55 H Fenwick and G Phillipson, Media Freedom under the Human Rights Act (Oxford: OUP 2006), p. 1070.

56 Ibid. p. 1100. 
to be an "impermissible slight (sic) of hand". 57 They asserted that the recognition of reputation as a component of Article 8 was the "careless" and "illegitimate" result of "overworked judges and their registrars churning out decisions". ${ }^{58}$ In short, they viewed the linkage between reputation and privacy as a "brazen", "plainly wrong . . . aberration", and the fruit of European judges" "unprincipled and unprecedented frolics". 59 Perhaps importantly, they also noted that such references were absent from other - arguably seminal - cases that laid down fundamental principles for the defamation area. ${ }^{60}$ The development was also criticised by Millar, who lamented the fact that:

there has been no explanation as to why this interpretation of art. 8 should suddenly have been arrived at, when it eluded the drafters and the entire preceding generation of Strasbourg judges. Nor is there any attempt to answer the obvious point that reputation, and certainly the most exposed part of it, lies in the public domain. It resides in the estimation of people who do not actually know the complainant personally, though they may know him or her as a public figure. Why should this be considered part of private, rather than public, life? ${ }^{61}$

Given the absence of any explanation as to quite why Article 8 should be interpreted so as to protect reputation, it is understandable that the early commentary on the development was critical. In light of the growing weight of authority on the general point, however, it is perhaps better to focus energy on understanding the development and seeking to shape its parameters in a coherent manner. ${ }^{62}$

\section{Remedial underpinning: emergent justifications for Article 8 protection}

Notwithstanding the increasingly consistent message deriving from the caselaw on the coverage of reputation by Article 8, a fundamental question is obviously begged. Reputation - by dint of being determined by aggregating the appraisals made of an individual by other people - is quintessentially public in nature. To gain legitimacy beyond its bare positivity therefore, the emerging caselaw must provide a persuasive answer as to why reputation should be protected as an aspect of one's private or family life. In a number of more recent decisions, judges of both the Strasbourg and domestic courts have recognised the need for better foundations to be provided for the emergent jurisprudence. There has also been concern that Article 10 should not be too readily deposed from its formerly pre-eminent role in cases involving expression. ${ }^{63}$ Different views have been expressed as to why protection is afforded relying variously on the public-private divide, the concept of human dignity, the contribution of reputation to psychological integrity, and the

57 G Robertson and A Nicol, Media Law 5th edn (London: Sweet \& Maxwell 2007), p. 67.

58 Ibid.

59 Ibid. p. 70.

60 Ibid. p. 68. They cited Steel \& Morris v United Kingdom (2005) 41 EHRR 22, at [87]; Stoll v Switzerland (2008) 47 EHRR 59, at [43]; and Selisto v Finland (2006) 42 EHRR 8, at [46].

61 Millar, "Whiter the spirit?", n 8 above, p. 282.

62 Legal attempts to have the Strasbourg court redress what is seen as an aberrant line of jurisprudence continue, however, for instance in the submission of the Media Lawyers Association in respect of the Grand Chamber's consideration of Springer v Germany (Application No 39954/08) and Von Hannover v Germany (Application No 40660/08), available at http://inforrm.wordpress.com/2010/09/16/von-hannover-and-springer-v-germanythe-media-intervention/ (accessed September 2011). For a view on the emergence of this jurisprudence that presents the development as entirely natural and unproblematic, see D Spielmann and L Cariolou, "The right to protection of reputation under the European Convention on Human Rights" in D Spielmann, M Tsirli and P Voyatzis (eds), The European Convention on Human Rights: A living instrument (Brussells: Bruylant 2011), pp. 401-25.

63 See, for example, Karako v Hungary (2011) 52 EHRR 36, at [20], and the partly dissenting opinion in Lindon, Otchakovsky-Laurens and July v France (2008) 46 EHRR 35. 
impact of libel on personal relationships. A second-level question has been that of whether Article 8 is invoked by every instance of harm to reputation (albeit that with at least the first explanation for Article 8 coverage the answer to this query is given by default).

\section{PUBLIC-PRIVATE DIVIDE}

The first suggestion concerning precisely when reputational harm should fall within the ambit of Article 8 has been that the protection should be afforded only where libels relate to private matters. Where false and defamatory statements concern public conduct, it is supposed, the adequacy of domestic libel laws should be assessed only under the rubric of Article 10(2). This view has scholarly support of some longevity. Writing in 1973, Velu argued that while:

it is certain that the right to honour and reputation is not set forth as such in the Convention ... it does not follow that [it] does not protect this right in any way. An attack on a person's honour or reputation may relate either to his private or to his public life. To the extent that it concerns his private life ... it constitutes a violation of the right safeguarded by Article 8(1) ... the Convention does not protect the individual against attacks on honour or reputation relating to his public life. ${ }^{64}$

More recently, Fenwick and Phillipson suggested that imputations regarding the performance of public functions should not give rise to any Article 8 interest. ${ }^{65}$

This is sensible insofar as one conceives of the private sphere as a physically and psychically sealable domain. Ultimately, however, this line of thinking is unsatisfying. Moreover, it coheres with neither the general tenor of Strasbourg jurisprudence, ${ }^{66}$ nor the focused consideration given therein to Article 8 and reputation. ${ }^{67}$ First, as a matter of practicality it would often be difficult to distinguish the public dimension of an individual's life from the private. The dividing line is at best fuzzy, on occasion non-existent. Secondly, a libellous imputation that relates directly - for example - to an individual's professional competence may have a debilitating effect on that person's psychological readiness to establish and develop personal relationships. Indeed, the compartmentalising of different aspects of life is less likely to be perceived as normal behaviour as it is evidence of some dissociative neurosis. ${ }^{68}$

\section{HUMAN DIGNITY}

A second suggestion as to why and when reputation should be covered by Article 8 has involved the linkage to the concept of human dignity. This idea was prominent in the first of two cases decided in late 2007 in which the European Court was called on to assess whether national criminal defamation laws properly balanced the desire to respect freedom of expression against the need to protect the reputation of the impugned parties. In a concurring judgment in Lindon, Otchakovsky-Laurens and July v France, Judge Loucaides

64 J Velu, "The European Convention", n. 51 above, p. 42.

65 Fenwick and Phillipson, Media Freedom, n. 55 above, p. 1100. This was explicitly a preliminary assessment (p. 1069). At another point the authors' discomfort with the development in the jurisprudence saw them concede that Article 8 must now be considered relevant in the context even of imputations regarding a person's discharge of official duties, but that in such circumstances the factor should be afforded "a relatively low weight" (p. 1100).

66 See, for example, Niemietzv Germany (1993) 16 EHRR 97, at [29].

67 With regard to Article 8 and reputation, this line of thought was expressly rejected in Pfeifer v Austria (2009) 48 EHRR 8, at [35]. See also the dissenting judgment of Judge Zagrebelsky in Armoniene v Lithuania (2009) 48 EHRR 53, at [O-I4].

68 A Goldman and A Jacobs, "Why everyone is going compartmental", The Guardian, 14 January 1999. 
contended that the approach based solely on assessing the necessity and proportionality of restrictions under Article 10 involved the underestimation of the centrality of reputation, which he deemed to be of "sacred value for every person". ${ }^{69}$ Novelly, he associated this "right to reputation" with the separate concept of individual human dignity. ${ }^{70} \mathrm{He}$ then proceeded to explain that reputation "requires more extensive and direct protection" such as would be provided were it properly "safeguarded as a human right under the Convention". 71 The judge was clearly aware that his reading would "[lead] inevitably to a more effective protection of the reputation of individuals vis-à-vis freedom of expression", 72 and that it would become "more difficult to defend a defamatory statement for purposes of Convention protection". ${ }^{73}$ Nevertheless, he did not expand on his justification for such a fundamental shift beyond the level of bombastic rhetoric. This concept was picked up in a recent lecture given by Heather Rogers QC when highlighting the jurisprudence of the South African courts on that country's constitutional principle of human dignity. ${ }^{74}$ Ultimately, however, she concluded only that this and other influences will see courts become "likely to look more and more at what is "proportionate".

The problem with citing human dignity as a basis for protecting reputation within Article 8 , is that it does not amount to a specific justification, and cannot be used to differentiate the particular circumstances in which protection should be afforded from those in which it should not. The principle is at once everything and nothing:

69 (2008) 46 EHRR 35, at [O-I10]. The case concerned an author's recreation of actual events in a fictional form in a book entitled The Trial of Jean-Marie Le Pen. The text recounts the racist murder of a young North African man and subsequent trial of his attacker. It suggests that as leader of the Front National the eponymous Le Pen was morally culpable for the devastating actions of his supporters. Following the finding that the fictional work was intended to identify the real-life Le Pen, the author and publisher were convicted for criminal defamation. A follow-up story in the Libération newspaper also resulted in a criminal prosecution. The majority of judges in the Strasbourg court adopted the standard approach and conducted an assessment of whether the right to freedom of expression was outweighed by the need to vindicate the right to reputation as one of the legitimate purposes stipulated in para. 2 of Article 10. Having conducted this exercise, they concluded that justice fell in favour of the restrictions imposed by the French law of defamation. Notably, four judges offered a strongly dissenting judgment in which they emphasised the centrality of freedom of expression in a democracy, the fact that the subject of the defamation was a political figure (and, a fortiori, one who himself engaged in virulent forms of discourse), and the importance of recognising the artistic form in which the material was presented. They found that there had been breaches of the expression right in respect of each of the three applicants, and that to conclude otherwise the European Court had foregone its normal supervisory rigour and merely adopted the impugned views of the French courts. In particular, they highlighted that, out of the 138-page novel, only three lines were ultimately considered to be defamatory by the Strasbourg court, and that this was deemed sufficient to justify the official response.

70 Ibid. at [O-I6]. An implicit association between reputation and human dignity was made previously in the concurring opinion delivered by Judge Thomassen in Chamy v France (2005) 41 EHRR 29, at [O-I4].

71 Ibid. at [O-I6]-[O-I10]. A reasonable reservation can be raised over Judge Loucaides' rationale in this case, as in part it seemed motivated by a pragmatic assessment that this would be the most convenient means judicially to constrain an overbearing media industry. He warned that "one should not lose sight of the fact that the mass media are nowadays commercial enterprises with uncontrolled and virtually unlimited strength, interested more in profitable, flashy news than in disseminating proper information to the public, in controlling government abuse or in fulfilling other idealistic objectives. And although they may be achieving such objectives incidentally, accidentally or occasionally, even deliberately, they should be subject to certain restraint out of respect for the truth and for the dignity of individuals . . . Like any power, the mass media cannot be accountable only to themselves. A contrary position would lead to arbitrariness and impunity, which undermine democracy itself." (at [O-I13]) Such thinking has been criticised by Eric Barendt among others see "What is the point of libel law?" (1999) 52 Current Legal Problems 111-25, pp. 112-13.

72 (2008) 46 EHRR 35 at [O-I7].

73 Ibid. at [O-I8]. Judge Loucaides reiterated his views in extra-judicial writings - see, for example, The European Convention on Human Rights: Collected essays (Leiden: Martinus Nijhoff 2008), pp. 143-66.

74 The text of the speech is reproduced as H Rogers, "Is there a right to reputation?", Inforrm, 26 and 29 October 2010. See also, Milo, Defamation, n. 2 above, pp. 22-3. 
the use of "dignity", beyond a basic minimum core, does not provide a universalistic, principled basis for judicial decision-making in the human rights context, in the sense that there is little common understanding of what dignity requires substantively within or across jurisdictions. The meaning of dignity is therefore context-specific, varying significantly from jurisdiction to jurisdiction and (often) over time within particular jurisdictions. Indeed, instead of providing a basis for principled decision-making, dignity seems open to significant judicial manipulation, increasing rather than decreasing judicial discretion . . dignity provides a convenient language for the adoption of substantive interpretations of human rights guarantees which appear to be intentionally, not just coincidentally, highly contingent on local circumstances. ${ }^{75}$

Human dignity is agreeable to everyone but adequately definable by no one. Hence, in the legal context, it becomes a malleable juridical concept ripe for exploitation. Where the idea of human dignity may potentially have more purchase, however, is in its association with the more empirical concept of psychological integrity.

\section{PSYCHOLOGICAL INTEGRITY}

The third possibility mooted by the courts as to when Article 8 should encompass a right to reputation invokes the concept of psychological integrity. The relevance of this theme for the defamation context was developed for the first time in Pfeifer $\mathrm{v}$ Austria, ${ }^{76}$ the second case decided in late 2007 in which the European Court was called on to assess national criminal defamation laws. ${ }^{77}$ Perhaps most importantly, that case erased any lingering doubt as to whether reputation is encompassed by Article 8. For the first time, the court

75 C McCrudden, "Human dignity and judicial interpretation of human rights" (2008) 19 European Journal of International Law 655-724, abstract. Professor Feldman concurs: "few people would argue that dignity, in the abstract, is unimportant. On the other hand, the meaning of the word is by no means straightforward, and its relationship with fundamental rights is unclear. The notion that dignity can itself be a fundamental right is superficially appealing but ultimately unconvincing." (D Feldman, "Human dignity as a legal value: Pt 1" (1999) Public Law 682-702, p. 682); "dignity [is] a highly complex concept. The content of its central core is not clear, making it an uncertain guide . . human dignity may refer to characteristics or norms; it may relate to individuals, social groups, or the entire species; and it may be based on subjective or objective assessments of what amounts to a dignified way of life . . . the power of dignity as a value to inform human-rights decision-making cannot hide the weaknesses of dignity as a basis for rights. It can never be more than one of a number of values, principles and policies which pull decision-makers in different directions ... protecting dignity indirectly through interpreting and enforcing other rights in the light of dignity is potentially valuable but far from unproblematic. The value offers judges an instrument with which they could subvert the proper relationship between themselves and the legislature in a democracy, or undermine respect for individual autonomy. Important as dignity may be, the law can sensibly only protect people indirectly against violations of their dignity, and even that requires careful thought" ("Human dignity as a legal value: Pt 2" (1999) Public Law 61-76, p. 76).

76 In the earlier private information case of Von Hannover v Germany (2005) 40 EHRR 1, the court had explained that "the guarantee afforded by Article 8 of the Convention is primarily intended to ensure the development, without outside interference, of the personality of each individual in his relations with other human beings" (at [50]). See also, $X$ and $Y \mathrm{v}$ the Netherlands (1986) 8 EHRR 235, at [22]; Raninen $\mathrm{v}$ Finland (1998) 26 EHRR 563, at [63]; Niemietz v Germany (1993) 16 EHRR 97, at [29]; and Botta v Italy (1998) 26 EHRR 241, at [32]. This was one step in the interpretation of the Article 8 right that has seen it become almost a "general charter of individual autonomy" that may in principle impugn any restraint on individual choice - see M W Janis, R S Kay and A W Bradley, European Human Rights Law: Texts and materials 3rd edn (Oxford: OUP 2008), p. 374. See also G Marshall, "A right to personal autonomy at the European Court of Human Rights" (2008) European Human Rights Law Review 337-56.

77 (2009) 48 EHRR 8. Pfeifer - the editor of a Jewish community magazine - had published a critique of an earlier article written by a professor in which he had supposedly trivialised the crimes of the Nazi regime in pre-war Germany. Criminal proceedings were subsequently brought against the professor for holocaust denial, but he committed suicide before their culmination. Later articles in the Zur Zeit magazine charged Pfeifer with hounding the professor to his death. He sued for defamation in the Austrian courts, but lost his case. 
determined that an applicant's right to reputation outweighed the countervailing interest in freedom of speech. ${ }^{78}$ In doing so, it asserted that a person's reputation forms part of their personal identity and psychological integrity and - building on the Von Hannover case - that it therefore falls within the scope of his or her "private life". ${ }^{79}$ This was said to be the case even where "that person is criticised in the context of a public debate". 80 The court did not develop a deeper explanation as to why one's reputation should be understood as contributing to one's psychological integrity, nor did it reflect on the question of whether this would always be the case. This explanation of the coverage of reputation by Article 8 was subsequently confirmed by the European Court of Human Rights in Karako v Hungary. ${ }^{81}$ The court reiterated that "the Convention . . extends the protection of private life to the protection of personal integrity", and that "this approach itself results from a broad interpretation of Article 8 to encompass notions of personal integrity and the free development of the personality". 82

A further feature of the decision in Karako is also noteworthy: the court strongly emphasised the variability of Article 8 coverage of reputation. It noted "a clear distinction, ubiquitous in the private and constitutional law of several Member States, between personal integrity and reputation", 83 and that "personal integrity rights falling within the ambit of Article 8 are unrelated to the external evaluation of the individual". ${ }^{84}$ Having distinguished harm to an individual's psychological integrity from harm to other people's perceptions, the court explained that only when a libel was sufficiently serious would it be liable to impinge upon personal integrity and hence invoke Article $8 .{ }^{85}$ While the reasoning of the court is consistent with that in Von Hannover, this was not an approach that had been adopted explicitly in previous cases. It has been confirmed, however, on a number of occasions since. ${ }^{86}$ That Article 8 does not protect reputation in all circumstances has been acknowledged in domestic jurisprudence. ${ }^{87}$ This approach has the merit of clearly differentiating two aspects of reputation. Reputation as it affects personal dignity or psychological integrity, and reputation as property or quasi-property. The dimension of reputation that is appropriately conceived as a property interest is not unimportant, 88 but

78 Similar determinations have since been reached in two further cases: Petrencov Moldova [2011] EMLR 5 and Petrina v Romania 78060/01 [2009] ECHR 2252 (6 April 2009).

79 Ibid. at [33]-[5]. It followed therefore that the main issue became whether the state, in the context of its positive obligations under Article 8, had achieved a fair balance between the applicant's right to protection of his reputation (an element of his "private life") and the other party's right to freedom of expression guaranteed by Article 10 of the Convention (at [38]). While dissenting from the substance of the court's judgment, Judge Loucaides expressed his "great satisfaction at the clarity and firmness with which, for the first time, a judgment of this Court has made it clear that a person's right to protection of his or her reputation is protected by Article 8 as being part of the right to respect for private life" (at [O-I11]).

80 Ibid. at [35].

81 (2011) 52 EHRR 36.

82 Ibid. at [21].

83 Ibid. at [22].

84 Ibid. at [23].

85 Ibid.

86 See, for example, Av Norway 28070/06 [2009] ECHR 580 (9 April 2009); Polanco Torres and Movilla Polanco v Spain 34147/06 unreported (21 September 2009). It was contested in Karako itself, however, in a partly concurring judgment delivered by Judge Jociene who considered that the prior caselaw had been consistent in finding reputation always to fall within Article 8.

87 See, for example, Flood v Times Newspapers [2009] EWHC 2375, at [141].

88 See, G S Bower, A Code of the Law of Actionable Defamation 2nd edn (London: Butterworths 1923), p. 240; T Starkie, A Treatise on the Law of Slander, Libel, Scandalum Magnatum and False Rumours 1 st edn (London: J \& W T Clarke 1813), p. 12. See also, Doley and Mullis, Carter-Ruck, n. 18 above, at 2.12-15. 
there must be real concerns over affording it protection under Article 8 when it is inherently an extrinsic, perhaps a financial, form of harm.

Importantly, this approach is coherent with the social psychology canon. ${ }^{89}$ In that discipline, for over one hundred years, it has been absolutely standard, generally accepted knowledge that the opinions of others become incorporated into the individual's sense of self-worth. In 1902, Charles Cooley developed the framework of the "looking-glass self". 90 In 1934, George Herbert Mead described a similar process, and observed that "we are more or less unconsciously seeing ourselves as others see us". ${ }^{91}$ Given that social psychology tells us that the perceived level of esteem that we think others hold for us substantially affects our judgments of self-worth, it is not difficult to appreciate why libellous publications might impact upon an individual's sense of self-esteem. It is clear that defamatory statements can impact upon an individual's capacity to engage in society. As Strasbourg jurisprudence has drawn on the concepts of human dignity and autonomy to expand the coverage of Article 8 to encompass not only a person's physical but also their psychological integrity, it is perfectly reasonable to contemplate a Convention right to the protection of reputation. It is not reasonable to suggest that this will happen on every occasion that a libel is published.

\section{IMPACT ON PERSONAL RELATIONSHIPS}

Interestingly, when delivering the unanimous decision of the Supreme Court in Guardian News and Media $L t d,{ }^{92}$ Lord Rodger suggested that the protection of reputation still falls within Article 8 even where the libel in question is deemed insufficiently serious to bear on the claimant's psychological integrity. This may be to set off on a hunt for the "snark". Certainly, the view expressed by the Supreme Court in Guardian News and Media Ltd would appear to require a fourth explanation as to why Article 8 should be read as extending coverage to reputation. This concerns the impact of reputational harm on the capacity of an individual to engage in relationships with other members of the community. Lord Rodger explained that "the Court is really being invited to consider the impact of publication ... on [the applicant's] reputation as a member of the community in which he lives and the effect that this would have on his relationship with other members of that community". ${ }^{93}$ His Lordship must have been envisaging something other than the impact of a libel on a claimant's psychological integrity as this was explicitly ruled out on the facts in Karako. The additional basis can only have been the influence of the libel on the

89 This is not an entirely novel idea in the legal literature. L McNamara has drawn on anthropological literature to make a similar point: see Reputation and Defamation (Oxford: OUP 2007), pp. 44-6. Moreover, Barendt has mused that "sociologists and psychologists would, I imagine, agree that the esteem in which we are held by others is an integral aspect of our own dignity and self-esteem . . . to allege that someone is, say, seriously incompetent or dishonest may well damage the esteem in which he or she is held by others and consequently would his or her self-esteem. Such allegations may additionally cause significant economic damage ... it is this argument which persuades me that there is a point to libel law", "What is the point?", n. 71 above, p. 116). In Barendt's view, however, "a right to human dignity, or to an aspect of it such as self-esteem, is far too vague and amorphous to provide a basis for a legal cause of action", p. 117).

90 C Cooley, Human Nature and the Social Order (New York: Scribner 1902).

91 G H Mead, Mind, Self and Society from the Standpoint of a Social Behaviorist (Chicago: University of Chicago Press 1934), p. 68. Subsequently, these formulations have been revised somewhat and three components of selfworth have been identified: self-appraisals; the actual appraisals made by others, and the individual's perceptions of the appraisals made by others (or "reflected appraisals"). Interestingly, the research indicates that there is a stronger relationship between reflected appraisals and self-appraisal, than between actual appraisals and self-appraisals.

92 [2010] UKSC 1, at [37]-[42].

93 Ibid. at [42]. 
behaviour of other people towards the claimant. That is, the fact that a libel may cause other people to shun, avoid or think less of the individual to whom the imputation related.

It is open to question whether this explanation as to why Article 8 should extend to cover reputation is sustainable or appropriate. Most importantly, it is based upon a misreading of precedent. Despite Lord Rodger's view to the contrary, the reading of Karako presented in Guardian News and Media Ltd is plainly at odds with the European judgment. This is important, not least because the Strasbourg court has accorded the Karako decision Level 1 status, entailing that in the court's judgment it has made "a significant contribution to the development, clarification or modification of its case-law". His Lordship suggested that Karako involved a factual circumstance in which the case for applying Article 8 based on psychological integrity had not been made out. Yet, he considered that the Strasbourg court had proceeded to balance Articles 8 and 10, on the assumption that Article 8 was engaged on the other basis that he then set out. He explained that a number of paragraphs of the Strasbourg judgment would otherwise not make sense. ${ }^{94}$

The problem with this analysis is twofold. First, it appears to run contrary to the clear dicta of the court to the effect that Article 8 is not concerned with the external evaluation of the subject of a defamatory statement. Second, in the paragraphs highlighted by Lord Rodger, the Strasbourg court in fact undertook a fleeting analysis under Article 10(2); it did not offer any balancing of Articles 8 and 10. While the slight ambiguity of the language used there does conceivably leave open the interpretation favoured by Lord Rodger, two further factors definitively rule it out. On the one hand, the caselaw cited by the Strasbourg court - Feldek v Slovakia and Scharsach v Austria - were referred to precisely because they set out the analytical method to be adopted when considering Article 10(2), not when balancing Articles 8 and $10 .{ }^{95}$ On the other hand, had the court in fact proceeded on the basis that some Article 8 right had been restricted by the publication then, as Lord Rodger noted, it would have been in the territory of balancing the Article 8 and 10 rights. Notably, the court is traditionally cautious in this scenario, tending in all but the most unusual of circumstances to respect assessments made by the domestic court in recognition of the "margin of appreciation". 96 Lord Rodger appears to have been untroubled by the absence of any reference to this doctrine in the key paragraphs. ${ }^{97}$ Had the Strasbourg court in fact been undertaking the balancing exercise that Lord Rodger suggested, it would have been highly irregular for there to have been no such mention. By placing the store that he did in a small number of ambiguous paragraphs of the Strasbourg judgment, Lord Rodger was seriously compounding a minor error made by the European Court. ${ }^{9}$

This is not to contend that the absence of any legal precedent for Lord Rodger's fourth explanation of the coverage of reputation should automatically preclude its relevance. Given the expansionary tendency of the interpretations afforded to Article 8, it may only

94 Specifically, paras 24-9 - see [2010] UKSC 1, at [41].

95 29032/95 [2001] ECHR 463 (12 July 2001), at [72]-[4], and (2005) 40 EHRR 22, at [30] respectively.

96 In Evans v United Kingdom (2008) 46 EHRR 34, for example, the court noted that "there will . . usually be a wide margin if the State is required to strike a balance between competing ... Convention rights" (at [77]).

97 Compare the references to the doctrine in A v Norway 28070/06 [2009] ECHR 580 (9 April 2009), at [66]; Petrenco v Moldova [2011] EMLR 5, at [54]-[6]. The court in Karako did make brief reference to the margin of appreciation to be afforded in the context of fulfilment of the state's positive obligation to meet the requirements of Article 8 - see (2011) 52 EHRR 36, at [19].

98 The court in Karako had been wrong to proceed to consider the balance between the freedom of expression interest and reputation as a putative limitation under Article 10(2). It had no need and no jurisdiction to undertake this task. It was asked by the applicant to assess the legality of a restriction on what he supposed was his Article 8 right and not to review the legitimacy of a restriction on Article 10. Having concluded that no Article 8 right of the applicant had been restricted, the court should have ended its analysis. 
be a question of time before such an argument finds favour in Strasbourg. If the concept of "private life" is so elastic as to extend to cover one's right to establish and develop relationships with others, ${ }^{99}$ then it may seem natural for the responses of such people to libellous imputations to be taken into account. If so, Strasbourg jurisprudence would dictate that such others would include not only a person's familial or social intimates, but also wider acquaintances. ${ }^{100}$ It would be a leap, however, for the concept of privacy to be considered so elastic as to extend beyond the physical, psychological or moral integrity of the individual concerned also to encompass decisions made and actions taken by other people. It is conceptually more sound to align with Pfeifer, Karako and social science, and to draw the line after including the psychological impact on the mind of the affected person. In addition to doubts over its conceptual legitimacy, it might also be asked what this line of argumentation adds. There will not be many circumstances in which there will be an impact on external evaluations when the individual concerned does not also perceive this shift such that his or her psychological integrity is affected in some measure. It would seem strange for the court to proffer an argument that would in principle draw incidents into the sphere of an individual's private life that were considered unimportant by the person themselves.

\section{Ramifications of psychological integrity as the basis for Article 8 coverage}

On analysis then, the only coherent position on why Article 8 should be thought to require the protection of reputation is that developed by the majority in Karako: that personal integrity rights are inherent to every person independent of the evaluation of others; that Article 8 may be engaged where a person's reputation is besmirched, but that this happens only if a libel is such as to result in some impact on personal integrity. While many defamatory statements will have such an effect, not all will. That is, reputation per se is not protected by Article 8. In other cases, where an imputation does not undermine an individual's personal integrity, the individual and social interests in reputation would be taken into account under Article 10(2) as a possible basis for restricting the first paragraph right to freedom of expression.

Reliance on the justification for Article 8 protection for reputation that derives from the concept of psychological integrity allows more to be said on the question of specifically when the need to balance rights arises. It can also suggest factual circumstances in which a recognised Article 8 interest is likely to be strong or weak. Conversely, contemplation of the impact of a libel on psychological integrity can highlight scenarios in which only the disparate elements of Article 10 need be countenanced. In a number of cases, the domestic and Strasbourg courts have begun to engage in this exercise.

\section{A BALANCING OF RIGHTS}

A first ramification is that the mere fact that reputation can justifiably be said to be encompassed by Article 8 entails that a balancing of rights will often have to be undertaken. This fact is clear in the Strasbourg jurisprudence. ${ }^{101}$ At the domestic level, a mode of

99 See, for example, Niemietz v Germany (1993) 16 EHRR 97; Armoniene v Lithuania (2009) 48 EHRR 53, at [35].

100 In Niemietz v Germany (1993) 16 EHRR 97, the court considered that "it would be too restrictive to limit the notion to an 'inner circle' in which the individual may live his own personal life as he chooses and to exclude therefrom entirely the outside world not encompassed within that circle. Respect for private life must also comprise to a certain degree the right to establish and develop relationships with other human beings" (at [29]). It extended the reach of this idea to persons encountered in a professional or business context.

101 See, for example, White v Sweden (2008) 46 EHRR 3; Pfeifer v Austria (2009) 48 EHRR 175; Karako v Hungary (2011) 52 EHRR 36; A v Norway 28070/06 [2009] ECHR 580 (9 April 2009); Rukaj v Greece 2179/08 [2010] ECHR 905 (21 January 2010); Petrenco v Moldova (decision of 30 March 2010); Saaristo v Finland 184/06 [2010] ECHR 1497 (12 October 2010). 
analysis for such cases was set out by the House of Lords in $\operatorname{Re} S$ (a child). ${ }^{102}$ This comprises a new methodology to be applied to the assessment of defamation claims. Specifically, where both rights are engaged, the court must begin from the position that neither right has precedence. An intense focus on the comparative importance of the specific rights being claimed in the individual case will be necessary. The justification for interfering with or restricting each right must be taken into account, and finally the proportionality test applied to each. This methodology will operate at two levels. First, the relevant aspects of the law will be assessed in the abstract to ensure that they allow scope for a balancing of rights to be undertaken. There will be less room for general rules to determine outcomes in particular cases. "Bright-lines" do not sit well with rights-based jurisprudence. There must be scope for the particular circumstances of each case to influence outcomes. Second, judges will undertake an intense scrutiny of the facts of the case. The sometime need to undertake this exercise in the defamation context has begun to be recognised by the domestic courts. ${ }^{103}$

This balancing methodology is well established in the context of the claim for misuse of private information. It might be expected that the courts will adopt a similar approach in defamation cases. While the courts are already familiar with balancing in misuse of private information cases, however, the process is likely to be rather more convoluted in defamation cases. The misuse of private information claim is, in essence, a straightforward cause of action. Once a privacy interest is found to subsist, it requires the court directly to balance the privacy right of the claimant against the expression right of the defendant on the facts of the particular case (while also taking into account any relevant interests of third parties). Defamation, in contrast, is a relatively technical area of law, wherein claims will generally be rather more complicated. An individual case might raise any of a myriad of different legal questions depending on the underpinning factual circumstances, each of which will require its own rendition under the new methodology. In any given case, it may be necessary to weigh the relevant rights in respect of both the existence of the prima facie claim, and then the application of any defences. A range of such issues may arise in one and the same case.

When conducting the balancing exercise, judges must consider a number of factors. Thus, on one side will be the claimant's Article 8 interest in reputation. This may be nugatory, or if it does exist may be more or less strong depending on a range of variables. The nature of the information, the seriousness of the allegation, the credibility of the publisher, and the mode of and audience for the communication may all play a part in determining the extent to which the defamatory imputation might affect the claimant's perception of the harm caused to his or her reputation. For instance, the claimant would know that a publication in the Washington Post was more likely to be taken seriously by readers than the equivalent in the National Enquirer, a false allegation of paedophilia against a nursery worker would likely have more profound psychological consequences for the subject than inaccurate suggestions of sexual profligacy on the part of a celebrity. So too, where the allegation relates to the claimant's moral character, is made in a national newspaper and the claimant is not a public figure or official, it is likely that greater weight will be given to the Article 8 right than if the claimant is a public figure and the imputation relates to physical characteristics or quality of work. Expression interests on the other side of the balance can also be more or less strong. Speech on a matter of scientific or political

103 See, for example, Re Guardian News and Media Ltd [2010] UKSC 1; Clift v Slough Borough Council [2009] EWHC 2375; Flood v Times Newspapers [2009] EWHC 2375 (QB); Brady v Norman [2010] EWHC 1215 (QB); Ronaldo v Telegraph Media Group Ltd [2010] EWHC 2710 (QB). 
controversy will be accorded significant weight, bolstered by the cumulative interest on the part of the wider public in receiving information on important matters of public concern. Where the subject matter of the story concerns the private life of a celebrity, the Article 10 interest is likely to be less strong.

A further point is worthy of general recognition: there is something artificial in this notional "balancing" exercise, at least to the extent that the metaphor implies that there is in every case some single, natural outcome to be found by the application of reason. Freedom of expression and respect for reputation are incommensurable goods. There is no easy equation for the exchange of a proportion of one for a given amount of the other. ${ }^{104}$ Ultimately, the judge must determine whether - in all the circumstances of the case - a remedy is appropriate. To accord with the principle of due process, the judge must ensure that all relevant factors are identified and accorded appropriate weight so as properly to inform the decision. Nevertheless, this decision relies on judgment. As Eady J has been assiduous in highlighting in the context of privacy claims, when undertaking this task the judge must be alert to the risks of colouring legal judgments with personal attitudes. ${ }^{105}$ Such danger is inherent in the new methodology of balancing Convention rights and the intense focus on the particular facts upon which the exercise rests. Perhaps unfortunately, this methodology will always allow scope for criticism by those dissatisfied with outcomes. ${ }^{106}$ The safeguards against judicial bias include recusal, but routinely rely on the delivery of fully reasoned judgments and the availability of judicial appeal. Whether such safeguards are sufficient is a moot point.

\section{CLAimANTS WITH NO ARTICLE 8 INTEREST IN REPUTATION}

The psychological integrity explanation entails that there will be certain types of claimant for whom Article 8 can never be used to defend reputation. Some claimants possess no

104 See, generally, J Alder, "The sublime and the beautiful: incommensurability and human rights" (2006) Public Law 697; G Beck, "Human rights adjudication under the ECHR between value pluralism and essential contestability" (2008) European Human Rights Law Review 214; S Tsakyrakis, "Proportionality: an assault on human rights?” (2009) 7 International Journal of Constitutional Law 468. The concept of incommensurability is most associated with the scholarship of Isaiah Berlin.

105 In $C C$ v $A B$ [2006] EWHC 3083 (QB), Eady J noted that "there is a risk that with greater emphasis on applying an 'intense focus' to the particular facts, with the room this leaves for the making of individual judgments, differing outcomes on what may seem to be broadly comparable facts may be interpreted by onlookers as being explicable on the basis of arbitrary personal differences between the judges. That is plainly undesirable because it would undermine faith in the rule of law, but the danger has to be recognised as inherent in the 'new methodology' of balancing Convention rights", and hence that "it is all the more important, therefore, that the outcome of a particular case should not be determined by the judge's personal views or, as it used to be said, by 'the length of Chancellor's foot"' (at [27]).

106 Famously, just such criticism was offered of the performance of Eady $J$ in excoriating fashion in November 2008 by Paul Dacre, the editor-in-chief of Associated Newspapers, at the conference of the Society of Editors - see Society of Editors, "Paul Dacre launches conference with explosive speech", press release, 9 November 2008 (includes full text). Mr Dacre commented that "there is one remaining threat to press freedom that I suspect may prove far more dangerous to our industry . . concentrate . . on how inexorably, and insidiously, the British Press is having a privacy law imposed on it, which . . . [is] allowing the corrupt and the crooked to sleep easily in their beds ... this law is not coming from Parliament - no, that would smack of democracy - but from the arrogant and amoral judgments - words I use very deliberately - of one man ... freedom of the press, I would argue, is far too important to be left to the somewhat desiccated values of a single judge who clearly has an animus against the popular press and the right of people to freedom of expression." This criticism was widely considered to be inaccurate, unfair, and palpably self-serving, and was roundly dismissed by a group of leading lawyers in a letter to The Times published on 11 November 2008. Nevertheless, it can also be seen as a predictable response to a changing legal environment, the parameters of which were not obviously sketched out in advance. See also, speech delivered by Mr Justice Eady at City University, London, 11 March 2010, transcript available at www.judiciary.gov.uk (accessed May 2011). 
psychological integrity. An obvious illustration is the trading corporation, but the same could be said of all non-human legal individuals. In domestic proceedings, such claimants are able to rely on Article 10(2) arguments only. Moreover, they would be unable to challenge the features of a domestic libel regime before the Strasbourg court. This point is uncontroversial: it is already a commonplace that corporations do not possess Article 8 rights of this type.

It is sometimes suggested that, like companies, any individual engaged in and criticised in respect of business, professional or public functions should be unable to claim any protection under Article 8 for reputational interests. To the extent that individuals can be conceived as merely economic actors such that reputational harm with be akin to property loss only, this is sensible. The "psychological integrity" explanation for drawing such reputational concerns within the rights-umbrella, however, militates against any generic limitation of the scope of protection. To the extent that a person builds their sense of selfworth in part on an appreciation of their competence, success or importance in an employment, professional or business context, the perception that one has lost the esteem of others in that context can be devastating. ${ }^{107}$ The existing jurisprudence on Article 8 has adopted a similar line, indicating that harm to economic or professional reputations may indeed fall within the ambit of the Convention right. In Niemietz v Germany, for example, the Strasbourg Court asserted that:

there appears ... to be no reason of principle why [the] understanding of the notion of "private life" should be taken to exclude activities of a professional or business nature since it is, after all, in the course of their working lives that the majority of people have a significant, if not the greatest, opportunity of developing relationships with the outside world ... it is not always possible to distinguish clearly which of an individual's activities form part of his professional or business life and which do not. ${ }^{108}$

Moreover, almost all of the cases in the line of Article 8 reputation cases discussed above concern defamation of precisely this nature.

Notwithstanding the generality of this point, it must be recognised that a prima facie argument based on Article 8 may be weakened by the particular factual scenario involved. As explained in $\operatorname{Re} S$ (a child), ${ }^{109}$ cases involving the balancing of Articles 8 and 10 cannot be determined in the abstract; they must proceed on the basis of an intense scrutiny on the facts of the case. For example, it would be reasonable to assert that individuals acting in certain positions would expect to suffer "slings and arrows" as an occupational commonplace; that people operating in some contexts will often be inured by role and experience to the possibility of psychological harm deriving from even deliberately false

107 A parallel can be appreciated in the alienation and depression suffered by some individuals who experience unexpected and/or prolonged disengagement from the workplace, for example, on account of redundancy or unexpected incapacity.

108 Niemietz, v Germany (1993) 16 EHRR 97, at [29]. The court proceeded to suggest, questionably, that this was particularly true of a person engaged in a liberal profession for whom "work . . . may form part and parcel of his life to such a degree that it becomes impossible to know in what capacity he is acting at a given moment of time".

109 [2004] UKHL 47, at [17] (per Lord Steyn). 
criticism. This may apply, for example, to politicians generally, although it would be wrong to preclude exceptions. ${ }^{110}$ It would certainly apply to deliberate controversialists such as Jean-Marie Le Pen. ${ }^{111}$ Such people positively invite antagonistic critique. Arguments ranged against them may well benefit from stronger protection under Article 10 (given the social value of responding to controversial political viewpoints), but, in addition, the expected weight of the reputation-based privacy interest on the other side of the balance may at the same time be weakened. Again, though, this cannot amount to a general rule that those performing public functions should be precluded from asserting arguments based on Article 8. Context must remain important.

\section{TRIVIAL LIBELS}

For defamatory statements to invoke Article 8 they must be such as to impact on the psychological integrity of the subject of the imputation. Not all defamation disputes will involve imputations that are sufficiently poignant to impinge upon a claimant's psychological integrity, and hence not all will invoke his or her Convention right to privacy. This fact has been acknowledged by both domestic and Strasbourg judges. For instance, as noted above, in Karako v Hungary the court concluded that while Article 8 had previously been deemed to cover defamation, this had been only "sporadically" and "mostly when the factual allegations were of such a seriously offensive nature that their publication had an inevitable direct effect on the applicant's private life". 112 On the facts of that case, however, the applicant had been unable to demonstrate this effect. ${ }^{113}$ A similar view was expressed by the court in its later decision in $A$ v Norway: "in order for Article 8 to come into play, the attack on personal honour and reputation must attain a certain level of gravity and in a manner causing prejudice to personal enjoyment of the right to respect for private life". ${ }^{114}$

Quite where this boundary will be drawn remains moot. Importantly, there may be some divergence between the respective rules developed to date at the supranational and the domestic courts. The British courts have long accepted that any impingement on privacy

110 So much was suggested in Karako, at least as regards comment on public performance. Similarly, in Lingens $\mathrm{v}$ Austria (1986) 8 EHRR 407, speaking in the context of Article 10(2), the court noted that "a politician ... inevitably and knowingly lays himself open to close scrutiny of his every word and deed by both journalists and the public at large, and he must consequently display a greater degree of tolerance" (at [42]). It would be difficult to contend that such criticism might be personally debilitating for the politician in any but the most extreme scenarios. There is no double-counting in the strengthening through context of the Article 10 argument simultaneously with the weakening of any purported Article 8 argument. The former is based on the expectations of the public; the latter on those of the subject of the defamation.

111 In the dissenting judgment in Lindon (2008) 46 EHRR 35, four judges noted that "the status of the injured party is also a factor which comes into play in the determination of the admissible limits to the rights and freedoms protected ... public figures and politicians, on account of the responsibilities they bear, are exposed to criticism as a matter of course and are therefore required to show greater tolerance towards polemical discourse or even insults directed against them . . . as regards Mr Jean-Marie Le Pen, it may reasonably be argued that he should accept an even higher degree of tolerance precisely because he is a politician who is known for the virulence of his discourse and for his extremist views" (at [O-II15]-[16]. As Millar has commented, "Jean-Marie Le Pen could perfectly well have answered the attacks by the characters of Lindon, a solitary novelist, in political debate. It was not necessary in a democracy for a court to render Lindon a criminal at Le Pen's behest." - "Whither the spirit?", n. 8 above, p. 288. In other decisions, similar points have been made by the court in respect of Austrian politician Jorg Haider - see, Oberschlick v Austria (No 2) (1998) 25 EHRR 357, at [29]; Wirtschafts-Trend Zeitschriften-Verlags GmbH v Austria [2006] EMLR 8, at [37].

112 (2011) 52 EHRR 36, at [23].

113 Ibid. The applicant, who had been a Member of Parliament standing for re-election, had been unsuccessful in bringing a complaint for criminal defamation against an adversary who had published a flyer during the election campaign criticising the applicant on the basis that he regularly voted against the interests of his district.

114 Application No 28070/06, unreported judgment of 9 April 2009, at [64]. 
must achieve a certain level of seriousness before it will warrant the protection of Article 8: "this core right protected by Article 8, however protean, should not be read so widely that its claims become unreal and unreasonable". ${ }^{115}$ Whereas the Strasbourg jurisprudence based on Karako would appear to insist on a libel being very grave before an argument based on Article 8 can be sustained, however, there are perhaps indications that domestic decision-making may exclude only those cases in which harm to psychological integrity is minimal or trivial. ${ }^{116}$ This may be a preferable approach. In cases at the margin, it would avoid simply negating the existence of an Article 8 right, but would not prevent that factor from being accorded a suitably "light weight" in the balancing exercise such that any substantial Article 10 interest might see it outweighed.

\section{Balancing expression and reputation: the impact on English law}

While the prevailing influence in English libel law has long been freedom of expression, with the reputation of others posing only a potential limitation on that right, the expansion of Article 8 to cover reputation leaves such an approach no longer always tenable. The state is under a positive obligation to protect both freedom of expression and reputation. This requires the courts to engage in a careful balancing of the two rights with neither having a presumptive precedence over the other. The days when Article 10 could be considered a trump card are over. ${ }^{117}$ The new requirement has begun to have an effect both on the way in which English judges approach their task in defamation cases and in the shape of the substantive law. While this has not led to a wholesale rowing back from the decisions reached in the 1990s and early 2000s, it is clear that a second rebalancing is underway. While Lord Nicholls spoke in Reynolds of the appropriate starting point being freedom of expression and the need for the common law to be developed and applied in a manner consistent with Article 10,118 courts now articulate the need to find a balance between privacy and expression rights.

This "new approach" first found expression in Greene v Associated Newspapers in which the court was content to assume that the adequate protection of reputation falls within the positive obligations imposed on the state by Article $8 .{ }^{119}$ It was not until the last two or three years, however, that it has come to be firmly reflected in the way in which courts now deal with defamation cases. The High Court, ${ }^{120}$ the Court of Appeal ${ }^{121}$ and the Supreme Court ${ }^{122}$ have each affirmed that the correct approach is the application of the "ultimate balancing test" stated in $\operatorname{Re} S$. This judicial recognition of reputation as a protected right under Article 8, and the correlative requirement not automatically to accord precedence to expression rights has now begun to impact on the shape of the substantive law. This

115 See, for example, $R$ (on the application of Wood) v Commissioner of Police of the Metropolis [2009] EWCA Civ 414, at [22].

116 See further text accompanying n. 147 below.

117 Often, the dictum of Lord Justice Hoffmann in R v Central Independent Television plc [1994] Fam 192, at 203, is cited in reflecting this erstwhile position. In fairness, however, the full dictum should be offered: "it cannot be too strongly emphasised that outside the established exceptions [in Article 10(2)], or any new ones which Parliament may enact in accordance with its obligations under the Convention, there is no question of balancing freedom of speech against other interests. It is a trump card which always wins."

118 Reynolds v Times Newspapers [2001] 2 AC 127, at 200.

119 [2004] EWCA Civ 1462.

120 Floodv Times Newspapers [2009] EWHC 2375, at [141]-[2]; and Thornton v Telegraph Media Group [2010] EWHC 1414, at [25] (per Tugendhat J); Brady v Norman [2010] EWHC 1215, at [1] (per Eady J); Ronaldo v Telegraph Media Group Ltd [2010] EWHC 2710, at [31] (per Sharp J).

121 Floodv Times Newspapers [2010] EWCA Civ 804, at [21].

122 Re Guardian News and Media Ltd [2010] UKSC 1. 
"re-centring" can already be seen in at least some areas, and can be expected to have broader ramifications as appropriate cases bring relevant questions to the courts. The existing defences in libel law have and will likely continue to come under scrutiny, but the new approach will also likely bear on a number of other areas. ${ }^{123}$

\section{REVISITING DEFENCES: REBALANCING REYNOLDS?}

One area in which it has been mooted that Article 8 protection for reputation may have an impact is in respect of the Reynolds privilege for responsible journalism. ${ }^{124}$ Reynolds serves to protect publishers from liability where the subject matter of a publication is of public interest and those involved in the publication have acted responsibly in seeking to determine its accuracy. Thus, even where statements made are factually incorrect and seriously defamatory, liability can be avoided. Such protections were one object of the ire of Judge Loucaides in Lindon:

the case law ... has on occasion shown excessive sensitivity and granted overprotection in respect of interference with freedom of expression, as compared with interference with the right to reputation. Freedom of speech has been upheld as a value of primary importance which in many cases could deprive deserving plaintiffs of an appropriate remedy for the protection of their dignity. 125

Coad, a noted London libel lawyer, concurs:

[a] fundamental difficulty with the Reynolds defence is that ... [it] entirely robs the victims of "untrue and defamatory statements" ... of their well-established right to a reputation under UK law ... [and] under Article $8 \ldots$ while the sole "pressing social need" argument in favour of Reynolds is the "need" to preserve the media's profit margins. 126

Such criticisms tend to undervalue the importance of publication of statements on matters of public interest which, at the time that they are made, are understood to be accurate contributions to public discourse. Nevertheless, the emergent jurisprudence on the right to reputation requires some reflection.

One minor change to the English law has already been introduced in response to the new privacy-based jurisprudence. In Reynolds, Lord Nicholls had explained that the appropriate starting point for the law was freedom of expression, and that the House of Lords was responding to a need for the common law to be developed and applied in a manner consistent with Article 10. ${ }^{127}$ In particular, this entailed that, when considering whether a publication had been in the public interest or whether the non-exhaustive list of factors relevant to the question of whether the publisher had acted responsibly, "any

123 In what follows the focus is on aspects of the substantive law. The new jurisprudence may equally prompt revisionary consideration of procedural aspects of the law - consider, for example, the rules on interim injunctions as considered by the Court of Appeal in Greene v Associated Newspapers [2004] EWCA Civ 1462.

124 Reynolds v Times Newspapers [2001] 2 AC 127; Jameel v Wall Street Journal Europe [2006] UKHL 44.

125 (2008) 46 EHRR 35, at [O-I4]. Judge Loucaides further elaborated his critique by reference to harms caused by misinforming the public on matters of importance: "the opposite argument is equally strong: the suppression of untrue defamatory statements, apart from protecting the dignity of individuals, discourages false speech and improves the overall quality of public debate through a chilling effect on irresponsible journalism. The prohibition of defamatory speech also eliminates misinformation in the mass media and effectively protects the right of the public to truthful information."

126 J Coad, "Reynolds and public interest: what about truth and human rights?" (2007) 18 Entertainment Law Review 75-85. See also, J Coad, "Reynolds, Flood and the king's new clothes” (2011) 22 Entertainment Law Review 1-10.

127 Reynolds v Times Newspapers [2001] 2 AC 127, at 200. Importantly, Lord Nicholls did not at all underplay the countervailing reputational interests at stake (at 201). 
lingering doubts should be resolved in favour of publication".128 In Flood v Times Newspapers, Tugendhat J contemplated whether this statement could stand in light of the recognition that reputation has the status of a Convention right and that as such it is of equal importance in principle to freedom of expression. ${ }^{129}$ He determined that it could not: "the balance between protection of reputation and freedom of expression requires the same approach in whatever legal context it arises . . . there will be cases where following the course enjoined in [Reynolds] will or may make a difference to the fate of a Reynolds defence". ${ }^{130}$ In other words, in a defamation claim - just as in a privacy claim the court must carry out a "parallel analysis" and consider matters from the perspectives of both the claimant's Article 8 right to reputation and the defendant's Article 10 right to freedom of expression.

At first glance, it might reasonably be thought that the need to balance the expression and reputation interests in the context of what has proven to be a false - or at least not provably true - statement on a matter of public interest will require some amendment to the current law. By way of example, it may be that an additional hurdle requiring demonstration of a heightened public interest or proof of a higher degree of responsibility should be required in cases where the degree of Article 8 reputational harm has been very significant. On analysis, however, this would seem to be unnecessary. Notably, Tugendhat J expressed the view in Flood that "the approach of the House of Lords in Jameel [was] fully consistent with [the requirements of] $\mathrm{Re} S " .{ }^{131} \mathrm{He}$ considered that the need to accommodate the right to reputation was adequately met by existing factors already included explicitly in the analysis by Lord Nicholls. ${ }^{132}$ This view was subsequently endorsed by the Court of Appeal. ${ }^{133}$ It may be, however, that in future the enhanced juridical status of the harm caused to the claimant in this context will see a court require the responsibility of the publisher to extend post-publication so as to entitle the claimant to a declaration of falsity or a right of reply. The manner in which the Reynolds public interest defence currently operates masks the fact that the impugned publication has not been demonstrated to be true, the claimant is left without vindication of reputation, and inaccuracies that misinform the wider public are not corrected. It might also present the claimant whose Article 8 rights have been restricted with a significant costs bill for his or her trouble. ${ }^{134}$

\section{REVISITING DEFENCES: ABSOLUTE AND QUALIFIED PRIVILEGE}

A category of defences that may be peculiarly susceptible to revision under the right to reputation jurisprudence is that of privilege. ${ }^{135}$ Where absolute privilege exists, no claim lies

128 Reynolds $\mathrm{v}$ Times Newspapers [2001] 2 AC 127, at 205. Lord Nicholls' comment related specifically to the former of this pair of issues; the analysis in Flood focused on the latter.

129 [2009] EWHC 2375 (QB).

130 Ibid. at [136]-[46].

131 Ibid. at [142].

132 Ibid. at [146]. In particular, Tugendhat J cited the requirements that the more serious the allegation in terms, inter alia, of the prospective harm that would be caused to the individual by publication the more that would be required to demonstrate responsibility; that the subject of the story should be given an opportunity to comment, and that the gist of his or her side should be given.

133 Floodv Times Newspapers [2010] EWCA Civ 804, at [20] (per Lord Neuberger).

134 Elsewhere, the authors of this paper have suggested a design for a libel regime the practical effect of which would be that a Reynolds defence would be deployed only should the claimant be seeking special damages and only if the defendant was willing to bear the cost of running the defence - see A Mullis and A Scott, "Reframing libel: taking (all) rights seriously and where it leads" (2012) 63(1) NILQ 3, this volume.

135 For a complete discussion of the circumstances in which absolute and qualified privilege may arise see, W V H Rogers and P Milmo (eds), Gatley on Libel and Slander 11th edn (London: Sweet \& Maxwell 2008), chs 13 and 14; Doley and Mullis (eds), Carter-Ruck, n. 18 above, chs 11 and 12. 
in respect of any publication made on such an occasion. Under qualified privilege, the court seeks to identify whether a relationship exists between the maker of the statement and its recipient that gives rise to the necessity for communications between them to be protected. This might be either because the publisher acts under a duty to inform the recipient who in turn has a legitimate interest in receiving the information, or because the statement was made in furtherance or protection of some private or shared interest. Where such a relationship exists, then the occasion is privileged provided that the defendant was not malicious and that what was published was relevant and not excessive.

An area in which the new jurisprudence has already had some effect is that of the use of qualified privilege by public authority defendants. In Clift $\mathrm{v}$ Slough Borough Council, the fundamental issue was whether the usual principles of qualified privilege should still apply where the defendant is a public authority. ${ }^{136}$ If they did, then the public authority need show only that an established relationship requiring the flow of free and frank communications existed between publisher and publishee to satisfy the "duty-interest" test. The alternative view was that as a public authority, the defendant must go further and demonstrate that it has complied with its public law duties under the Human Rights Act 1998 (and, incidentally, the Data Protection Act 1998). Both Tugendhat J at first instance, and the Court of Appeal held that the latter view was correct. ${ }^{137}$ Under s. 6(1) of the Human Rights Act 1998, it is unlawful for a public authority to act in a way that is incompatible with a Convention right. It followed that where a public authority publishes information about an individual that interferes with his or her right to reputation under Article 8(1), this could only be lawful if justified under Article 8(2). The publication must be necessary and proportionate in a democratic society in pursuit of a legitimate aim such as the protection of the rights of others. Given that a public authority does not possess human rights, there was no question in that case of balancing countervailing rights in line with the approach set out in $\operatorname{Re} S .{ }^{138}$

Hence, the new jurisprudence on the right to reputation has dictated that a different approach must be taken to the existence of qualified privilege where the defendant is a public authority than has been the case as regards traditional qualified privilege. This may be only the first in a series of developments in this area of the law. Importantly, because

136 [2009] EWHC 1550. The claimant in Clift witnessed some anti-social behaviour in a park in Slough, and on the advice of the police rang the council's anti-social behaviour co-ordinator. This conversation went very badly, words were exchanged and Ms Clift terminated the call. She subsequently wrote a very strongly worded letter of complaint concerning the council officer's conduct. This complaint was rejected, and Ms Clift was informed that her own conduct on the phone and in subsequent letters amounted to "violent and threatening behaviour" as a consequence of which a "marker" was to be placed against her name for 18 months and shared with other council departments and government agencies within the borough by email and by placing her name on a "Potentially Violent Persons Register". Emails were sent to a wide range of council workers, including several who would be very unlikely to have any dealings with the claimant. Ms Clift commenced a claim for libel alleging that the communications meant that she was a violent person who had engaged in threatening behaviour on a number of occasions. The defendants sought to rely, inter alia, on qualified privilege but Tugendhat $\mathrm{J}$ held that the defence failed and his decision was affirmed by the Court of Appeal ([2010] EWCA Civ 1484).

137 Ibid.

138 Parochial Church Council of the Parish of Aston Cantlow and Wilmcote with Billesley Warwickshire v Wallbank. [2003] UKHL 37, at [8]; R (Mayor of the City of Westminster) v Mayor of London [2002] EWHC 2440, at [93]-[6]. On the facts, while the council had acted with a legitimate aim of protecting the safety of its staff, the circulation of the publications was greater than was necessary to accomplish that objective. The risk was a very limited one and certainly did not exist to those who worked in departments which the claimant was not likely to approach ([2009] EWHC 1550, at [84]). Moreover, there was simply no evidence of risk in to the staff of partner organisations (at [86]). Had there been a real danger to the physical or psychological integrity of council employees, their Article 8 rights may have been engaged and a parallel analysis required. 
Article 8 imposes positive obligations on the state to secure Article 8 rights to every person, it may be expected that the general development of the law on privilege must in future also be reviewed for coherence with the right to reputation.

Whether in the new era all the established categories of privilege can survive must be open to question. Generally, in the areas covered by privilege, there will be an expression right countervailing to the right to reputation. The essential problem is that the blanket nature of the privileges does not allow for any proper balancing exercise between rights. This general need for privilege to reflect an appropriate balance was recognised by Tugendhat $\mathrm{J}$ in Clift:

the historical cases show that the values set down in the Convention in 1950 as rights under Articles 8 (including the right to reputation) and Article 10 (including the right of freedom of expression in the giving of references and warnings) were not invented in 1950. These and some other Convention rights can be traced back, not only to the American Bill of Rights and the French Declaration in the eighteenth century, but also to the very beginnings of English law. So one thing that [the Human Rights Act] has achieved is to provide a means through which the courts can review the relative priority that the common law gave to those rights (which it already recognised), and adjust those priorities to meet contemporary needs. ${ }^{139}$

Each privilege will require assessment to determine whether the policy reflected in its structure is now Convention compliant. An exercise of this type has been undertaken with regard to the absolute privilege granted to MPs in respect of statements made in Parliament, which found that the current rule is consistent with both Articles 6 and 8 of the Convention. ${ }^{140}$ Even this review has been subject to criticism. ${ }^{141}$ It is a moot point whether, for example, the according of absolute privilege to a complaint by a victim of crime, ${ }^{142}$ or the according of qualified privilege to a person who responds to an attack, ${ }^{143}$ would be found similarly to accord adequate weight to the right to reputation. Precisely how the courts will deal with this set of concerns remains to be seen, but it is likely that some categories of privilege will be subjected to challenge on the basis that the public policy that originally justified their existence does not apply today. The availability of privilege in any particular case must become more fact-sensitive, and the courts must find means of weighing the claimant's Article 8 rights in the balance.

\section{REVISITING DEFENCES: RE-THINKING OF TRUTH AS AN ABSOLUTE DEFENCE}

It is trite law that, subject to the Rehabilitation of Offenders Act 1974, truth provides a complete defence in a defamation claim. The fact that the claimant might establish that they had suffered real distress or embarrassment as a consequence of the publication, or that

139 [2009] EWHC 1550, at [112].

140 Av United Kingdom (2003) 36 EHRR 51. Notably, there was some measure of dissension among the judges of the Strasbourg court in their respective analyses of the justifiability of an absolute immunity.

141 One commentator, for example, has noted that "this might not be the final word on the compatibility of Parliamentary immunity with human rights. It is even arguable that a domestic court could reopen the question ... the case should spur the Commons to consider reform, either by creating internal procedures that allow individuals some form of redress for serious abuses of privilege, or by creating a mechanism whereby privilege could be suspended in certain situations ... there is much that could be done to square parliamentary immunity with Arts 6 and 8 without risking the freedom of debate within the Chamber." - see N Barber, "Parliamentary immunity and human rights" (2003) 119 Law Quarterly Review 557-60, pp. 559-60.

142 Buckley v Daliziel [2007] 1 WLR 2933; Westcott v Westcott [2008] EWCA Civ 818.

143 See, for example, Adam v Ward [1917] AC 309. For a full explanation of the ambit of the privilege, see Rogers and Milmo, Gatley, n. 135 above, at 14.48ff.; Doley and Mullis, Carter-Ruck, n. 18 above, at 12.64-71. 
publication was not in the public interest is irrelevant. In a lecture in 2010, Eady J raised the question of whether the absolute nature of the justification defence could be sustained in the light of the new Article 8 jurisprudence. ${ }^{144}$ Having explained how the "secrecy" permitted in relation to so called "spent convictions" under the 1974 Act could be justified in human rights terms, his lordship posed the question whether the philosophy behind the Act - namely that rehabilitation is a good in itself that in limited circumstances justifies restrictions being placed on freedom of expression - may find itself extended to other inconvenient facts. As he put it:

compared with the distress and embarrassment it would occasion, the prospective exercise of freedom of speech [in publishing some true but seriously embarrassing fact] would not be sufficiently valuable or important. We might find ourselves losing one of our reasonably clear black and white distinctions (that between truth and falsehood). ${ }^{145}$

While it is clearly possible to construct an argument to this effect, and good reasons exist in some circumstances to allowing private and embarrassing information to be "forgotten", 146 truth should remain a complete defence to a defamation claim. Where the matter published is private or personal information, a claim already exists for misuse of private information. Little is to be gained by allowing a claimant also to sue in defamation. The international obligations of the state do not need to be satisfied in every particular in each cause of action, just satisfied somehow. Defamation law need not be considered in isolation. Where information published is true and not private, the public policy interest in always allowing publication is very strong.

\section{MisCELLANEOUS CONCERNS: THRESHOLD OF SERIOUSNESS IN DEFAMATION CASES}

In Thornton v Telegraph Media Group Ltd, Tugendhat J considered the question of what "defamatory" means. ${ }^{147}$ His starting point was that "a review of the word defamatory... requires some consideration of ... the tendency of each meaning to give effect to Article 8 and Article 10". ${ }^{148}$ As a preliminary conclusion, he noted that whatever definition of defamatory is adopted, "it must include a qualification or threshold of seriousness, so as to exclude trivial claims". ${ }^{149}$ Notwithstanding the early invocation of both Articles 8 and 10, Tugendhat $\mathrm{J}$ culminated his consideration by highlighting regard for the latter right only alongside the principle of proportionality. ${ }^{150}$ While such an explanation is entirely tenable, an additional support can be afforded to it by noting that Article 8 is not engaged where the nature of any attack on the claimant's reputation is not sufficiently serious to impact upon his or her psychological integrity. Such an approach would have been consistent with other

144 Speech delivered at City University, London, 11 March 2010, transcript available at www.judiciary.gov.uk (accessed May 2011). The judge also stated that "it may prove to be a sufficient answer as a matter of public policy that, in the case of defamation, damages are more often likely to provide an adequate remedy, whereas in privacy cases they are not. But the question at least needs to be thought about.” (p. 12)

145 Ibid. p. 9.

146 See further, V Mayer-Schonberger, Delete: The virtue of forgetting in the digital age (Princeton: Princeton UP 2009); P A Bernal, "A right to delete?" (2011) 2(2) European Journal of Law and Technology.

147 [2010] EWHC 1414 (QB).

148 Ibid. at [32].

149 Ibid. at [90].

150 In particular, he noted the accordance of his conclusions with the true interpretation of Lord Atkin's speech in Sim v Stretch [1936] 2 All ER 1237 and the development of the law recognised in Jameelv Dow Jones [2005] EWCA Civ 75 as arising from the passing of the Human Rights Act and its domestication of the expression right. 
comments made in the case in relation to "business defamation" and also with the wider privacy jurisprudence. ${ }^{151}$

\section{MisCELLANEOUS CONCERNS: BUSINESS DEFAMATION}

Business defamation has proved one of the most controversial issues in the current furore over libel reform. Lord Lester's Defamation Bill proposed that a body corporate would have to show that the publication "has caused or is likely to cause, substantial financial loss" before being allowed to bring a claim. ${ }^{152}$ While the question remains open for consultation under the Draft Defamation Bill, ${ }^{153}$ preventing corporates from suing has been a primary goal of some libel reformers. Whatever ultimately happens with the government's Bill, application of the new methodology is likely to prompt reconsideration of several issues relating to business defamation. The reason for this was identified by Tugendhat $\mathrm{J}$ in Thornton v Telegraph Media Group Ltd:

there is a further reason why cases of business defamation require separate consideration, whether or not there is a separate tort of "business defamation". What is at stake in a defamation reflecting on a person's character is now likely to be recognised as engaging that person's rights under Article 8. On the other hand, if an alleged defamation engages only a person's professional attributes, then what is at stake is less likely to engage their rights under Article 8, but may engage only their commercial or property rights (which are Convention rights, if at all, under art. 1 of the First Protocol). ${ }^{154}$

A number of points can be drawn from this dictum. First, most obviously implicit is the idea that not all attacks on reputation engage Article 8 . Where business defamation is concerned, Article 8 is not engaged and the only interest at stake is financial. Secondly, the concept of business defamation is extended from cases involving corporate parties, ${ }^{155}$ sometimes to those - as in Thornton itself - where the claimant is a private individual concerned about allegations of a lack of competence in business or professional life.

The practical consequences of this for business defamation are difficult to predict but two issues can be noted. First, it does not automatically follow from the recognition that corporate claimants do not have Article 8 rights in this context that the rule allowing them to sue even in the absence of proof of damage should be reconsidered. Standing in the way of such a reconsideration is the relatively recent decision of the House of Lords in Jameel $\mathrm{v}$ Wall Street Journal Europe, ${ }^{156}$ and the decision of the European Court of Human Rights in Steel \& Morris $\mathrm{v} U K{ }^{157}$ In the former, their Lordships held by a majority that a foreign company with a reputation in this jurisdiction could maintain a claim even in the absence of proof of any financial loss. In the latter case, the Strasbourg court held that allowing a multinational company to sue in defamation did not constitute a breach of Article 10. It

$151 \mathrm{R}$ (on the application of Wood) v Commissioner of Police of the Metropolis [2009] EWCA Civ 414, at [22] (per Laws LJ); $R$ (on the application of Gillan) $\mathrm{v}$ Commissioner of Police of the Metropolis [2006] UKHL 12, at [28] (per Lord Bingham).

152 Defamation Bill 2010, cl. 11.

153 Ministry of Justice, Draft Defamation Bill: Consultation paper CP3/11 Cm 8020 (Norwich: TSO 2011), pp. 139-46. 154 [2010] EWHC 1414 (QB), at [39].

155 In Hays v Hartley [2010] EWHC 1068, for example, Tugendhat J commented with regard to a claim brought by a corporate claimant as follows: "Companies enjoy certain rights under Art 8, and in some cases damage to reputation can be an interference with a person's rights under Art 8. But that is not this case. It follows that the only Convention right engaged in these proceedings is the right of the Defendant to freedom of expression under Art 10."

156 [2006] UKHL 44.

157 [2005] EMLR 314. 
might be argued that the courts in these cases gave insufficient weight to the conceptual nature of the interest protected by Article 8 and as a consequence overemphasised the weight of "corporate" reputation. This was certainly the view of the minority judges in Jameel. Nevertheless, judicial reversal of the rule seems unlikely.

Second, the Thornton decision recognises that some claims though brought by a private individual are analogous to business defamation and as such do not engage Article 8 rights. Thornton itself was a decision of this type in that one of the allegations imputed that the claimant engaged in journalistic practices that other journalists considered disreputable. Tugendhat $J$ stated in such a case that the test for what is defamatory is a different one than that which is applied where the libel is a personal one. ${ }^{158}$ Such an approach makes sense in light of a conceptualisation of Article 8 as concerned with the protection of personal integrity. A practical consequence is that, in future, claims by private individuals that their business reputation has been impugned may be more difficult to sustain. That said, difficulties are likely to arise in drawing the line between what is, and what is not, a case of business defamation. As discussed above, we live in a world in which - rightly or wrongly an individual's sense of self is often dependent not only on the perceptions of how highly regarded one is in the private sphere but also in one's work life. In that context, a damning indictment of professional competence will often be just as likely to affect an individual's self-esteem as one that imputes personal immorality. In consequence, while the distinction between business and personal defamation makes sense from an Article 8 perspective, care needs to be taken to avoid simplistically assuming that no attack on employment, professional, public or business competence engages Article 8.

\section{MISCELLANEOUS CONCERNS: THE SINGLE MEANING RULE}

A final aspect of the extant general law of defamation that may come under scrutiny in light of the protection afforded to reputation by Article 8 is the single meaning rule. This rule requires the court to select one meaning from the range of those that are reasonably possible as that which would be discerned by a hypothetical ordinary, reasonable reader. It is aimed towards simplifying the task of the jury when determining the extent and value in damages of harm caused by a defamatory imputation. In his half-hearted, but seminal, affirmation of the rule, Diplock LJ acknowledged that:

everyone outside a court of law recognises that words are imprecise instruments for communicating the thoughts of one man to another. The same words may be understood by one man in a different meaning from that in which they are understood by another and both meanings may be different from that which the author of the words intended to convey ... [and] where ... words are published to the millions of readers of a popular newspaper, the chances are that if the words are reasonably capable of being understood as bearing more than one meaning, some readers will have understood them as bearing one of those meanings and some will have understood them as bearing others of those meanings. 159

158 [2010] EMLR 25, at [33] and [36]-[49]. The judge described cases of business defamation as follows (at [33]): "a) Imputations upon a person, firm or other body who provides goods or services that the goods or services are below a required standard in some respect which is likely to cause adverse consequences to the customer, patient or client. In these cases there may be only a limited role for the opinion or attitude of right-thinking members of society, because the required standard will usually be one that is set by the professional body or a regulatory authority; b) imputations upon a person, firm or body which may deter other people from providing any financial support that may be needed, or from accepting employment, or otherwise dealing with them. In these cases there may be more of a role for the opinion or attitude of right-thinking members of society."

159 Slim v Daily Telegraph Ltd [1968] 2 QB 157, at 171. The rule was subsequently affirmed by the House of Lords in Charleston v News Group Newspapers [1995] 2 AC 65, and its use was described as "unexceptional" by Lord Nicholls in Bonnick v Morris (Jamaica) [2002] UKPC 31, at [22]. 
In the context of this potential multiplicity of meanings, the pathological consequences of the rule have been highlighted by the Court of Appeal when obviating the rule in the context of claims for malicious falsehood:

if the single meaning rule does achieve a fair balance in defamation law between the parties' competing interests, that would appear to be the result of luck rather than judgment ... the application of the rule can also be said to carry with it the potential for swinging the balance unfairly against one party or the other, resulting in no compensation in cases when fairness might suggest that some should be due, or in over-compensation in others. ${ }^{160}$

Lord Justice Rimer considered that "if the single meaning rule did not exist, I doubt if any modern court would invent it, either for defamation or any other tort". ${ }^{161}$ The single meaning rule is a legal fiction that pretends that the harm to reputation that results from all but the most likely meaning of those possible has simply not occurred. For this reason, it is unavoidably "unjust". ${ }^{162}$ In the context of Article 8 protection of reputation, such wilful ignoring of the infringement of rights is not tenable. Especially at a time when cl. 8 of the government's Draft Defamation Bill proposes the effective end of the role of the jury in the determination of meaning, ${ }^{163}$ there can be no justification for prolonging this artifice.

\section{MisCELlaneOUS CONCERNS: A SINGLE PUBLICATION RULE}

One likely revision to the law of defamation to arise out of the current legislative deliberations will be a move towards a "single publication rule". Clause 6 of the Draft Defamation Bill proposes the abolition of the existing multiple publication rule under which every new publication of a defamatory imputation gives rise to a separate claim. It has received widespread support. ${ }^{164}$ A single publication rule would prevent an action being brought in relation to a publication of the same material by the same publisher after a oneyear limitation period from the date of first publication of that material to the public or a section of the public. It is proposed, however, that the limitation period may be set aside under the discretion allowed to the court under s. 32A of the Limitation Act 1980.

The application of the multiple publication rule to the online context does generate some injustice and social detriment by creating perpetual liability. It is inappropriate, however, to address one admitted problem by pretending that another does not exist. Torts flow from harms caused. At whatever remove it is made from the first uploading of the impugned statement, each reading has the potential to harm the reputation of the person defamed. Indeed, secondary publication after the elapse of time may arguably, perhaps counter-intuitively, be more damaging than much initial publication. Often, only those with a particular interest in a subject or individual will be motivated to access the material at the later point in time, so that any impact on reputation may be especially poignant. In terms of damage to reputation, what often matters is who is reading material at a given time.

160 Ajinomoto Sweeteners Europe SAS v ASDA Stores Ltd [2010] EWCA Civ 609, at [43] (per Rimer LJ). A similar point has been made in other jurisdictions: "to insist upon an innocent interpretation where any reasonable person could, and many reasonable people would, understand a sinister meaning is to refuse reparation for a wrong that has in fact been committed" - see Entienne P/L v Festival City Broadcasters [2001] SASC 60, at [39]-[42].

161 Entienne $P / L$, see n. 160 above.

162 Ibid. at [31] (per Sedley LJ).

163 Ministry of Justice, Draft Defamation Bill, n. 153 above.

164 A majority of the Ministry of Justice Libel Working Group and of respondents to a previous government consultation recommended this course. Abolition was also recommended by the House of Commons Culture, Media and Sport Committee, Second Report: Press standards, privacy and libel, HC 362-I (2009-2010), at [229]. 
On occasion, the proposed new rule will frustrate justice. It does not allow for an appropriate balance to be struck between Article 10 rights to communicative freedom and competing Article 8 rights to reputation. Such occasions may be infrequent and they may be covered by the discretion of the court to set aside the limitation period for action under s. 32A of the Limitation Act 1980. At present, however, this is done only in exceptional circumstances, and it may not be reasonable to expect that judges will use this power to address the potential problems. Not every author of a defamatory statement - or every archivist of online content - is deserving of exoneration from liability. Yet, every victim of online libel does have a right to have his or her specific case considered and the legitimacy of the restricting of individual Article 8 rights to reputation assessed.

\section{Conclusions}

The Human Rights Act era has seen a re-centring of the law of defamation. Initially, this involved privileging freedom of expression over reputation as the courts sought to make English law Convention compliant. In more recent years, reputation has been recognised by the Strasbourg and English Courts as being potentially protected by Article 8, and this has required a new balancing methodology to be applied. In every case where both rights are engaged, the court must begin from the position that neither the claimant's Article 8 rights nor the defendant's Article 10 rights have precedence over the other. Instead, where these values are in conflict, an intense focus on the facts is necessary to determine the comparative importance of the specific rights being claimed in the individual case. The justification for interfering with or restricting either right must be taken into account, and the proportionality test must be applied to each.

While the basic framework of analysis has been restated, the shape that the English law will take is not easy to predict. Several reasons explain this. First, uncertainty is inherent in the methodology that English courts are now required to adopt. Every case in which Articles 8 and 10 are engaged would appear to require the courts to weigh their respective importance. In time, the weight the courts will apply to particular factors will become clear, as they have started to do in misuse of private information claims. It is worth remembering, though, that defamation is a much more complex cause of action than misuse of private information. Accordingly, it will take some time for this to happen. The foregoing discussion has sought to identify some of the factors that are likely to be treated as relevant by the courts, and offered some reflections as to the potential impact that the new methodology will have on the extant law. These reflections are necessarily tentative.

Second, while the courts have recognised that reputation may be protected by Article 8 , they have yet to offer a consistent explanation of why and when attacks on reputation will fall within that provision. Until such an explanation is given, the courts will face difficulties in shaping the law in the light of the new methodology. As has been explained, the decision of the European Court in Karako offers the most satisfactory explanation. Only where the attack on reputation affects an individual's psychological integrity should Article 8 be engaged. Where it does not, reputation is relevant only under article 10(2) as a personal and societal interest that may potentially limit or restrict the right to freedom of expression. To the extent that the Supreme Court suggests a different explanation in Re Guardian News and Media as to why and when reputation falls within Article 8, the decision is not consistent with Strasbourg authority and is conceptually unsound.

Finally, it seems likely that a new Defamation Act will become law in 2012. Uncertainty exists as to the final form this Act will take, but there are real concerns whether those charged with producing the law will pay sufficient attention to the fact that reputation, when protected by Article 8, is prima facie of equal weight to Article 10. There is not much 
evidence that they have done this so far. Instead, Parliament may pander to free speech interests and produce an Act that shifts the law in favour of freedom of expression. Such an approach would ignore our international obligations and would make it markedly more difficult for claimants to vindicate their Article 8 rights. That said, any new law would have to be interpreted in the light of the new methodology, and this may have the effect of taking the edge off any particularly egregious privileging of expression interests.

All in all, it seems likely that the law of defamation is set for a turbulent time. Even if the methodology that the courts are to adopt is clear, their failure to explain why reputation may be protected under Article 8, the uncertainty inherent in the methodology itself, and the potential new Defamation Act mean that future shape of the law is in the balance. Elsewhere, the current authors have offered a blueprint for the law that does seek properly to triangulate the interests of claimants, defendants and the wider public. ${ }^{165}$ In the absence of such wholesale and radical reform, English law is likely to carry on costing too much while satisfying no one. 